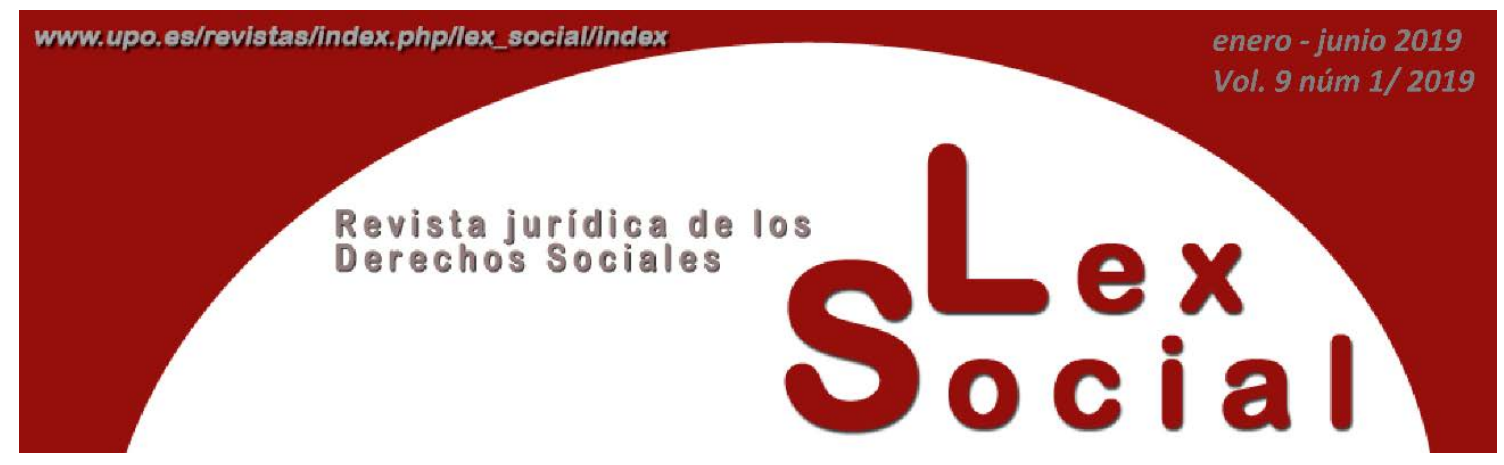

\title{
RETOS Y COMPROMISOS INTERNACIONALES PARA LA CONSOLIDACIÓN DEL ESTADO SOCIAL Y DEMOCRÁTICO DE DERECHO EN ESPAÑA
}

\section{CHALLENGES AND INTERNATIONAL COMMITMENTS FOR THE ACHIEVEMENT OF THE SOCIAL AND DEMOCRATIC STATE OF LAW IN SPAIN}

\author{
CARMEN SALCEDO BELTRÁN \\ Profesora Titular de Universidad \\ Departamento Derecho del Trabajo y Seguridad Social \\ Universidad de Valencia
}

Artículo recibido el 2 de febrero de 2019

Artículo aceptado el 17 de febrero de 2019

\section{RESUMEN}

El presente estudio se dedica a mostrar la desestabilización y amenaza que adolece en España uno de los hitos más importantes de la humanidad, como es el Estado Social y Democrático de Derecho y la necesidad de su restablecimiento y consolidación por la vía del respeto de los compromisos internacionales asumidos, en particular, respecto del Pacto de Derechos Económicos, Sociales y Culturales y de la Carta Social Europea.

A lo largo del mismo, se examinan los déficits existentes, puestos de manifiesto con las violaciones de derechos sociales constatadas y comunicadas por los respectivos órganos supranacionales de control de su cumplimiento, que deben ser corregidas y acatadas, como interpretación auténtica y vinculante, en cumplimiento del art. 96 de la Constitución Española y de la Ley 25/2014, de 27 de noviembre, de Tratados 
y otros Acuerdos Internacionales, así como los ineludibles retos a asumir.

Con ello, se fortalecería la legitimidad del país, se incrementaría la confianza de la sociedad en el Estado al atender las exigencias de los ciudadanos y, por derivación, la justicia social.

Palabras Clave: Protección internacional multinivel, derechos sociales, derechos humanos, Estado Social y Democrático de derecho, justicia social, Pacto Internacional de Derechos Económicos, Sociales y Culturales, Carta Social Europea

\section{Abstract}

The present study is devoted to highlighting the instability and threat that Spain suffers in relation to the Social and Democratic State of Law, as one of the most important milestones of humanity and the need for its restoration and consolidation through the respect of the international commitments, in particular, those concerning the International Covenant on Economic, Social and Cultural Rights and the European Social Charter.

Existing deficits, brought to light by the clear violations of social rights observed and reported by the respective supranational supervisory bodies, are thoroughly analysed and foreseeable challenges to be faced are also examined. As is pointed out, said violations must be remedied and promptly complied with, in line with an authentic and binding interpretation of Article 96 of the Spanish Constitution and of Act 25/2014, of 27 November 2014, on Treaties and other International Agreements.

Thus, by meeting the demands of its citizens, Spain's legitimacy would be reinforced, the public's confidence in the State would be restored and, ultimately, social justice would be strengthened.

KEY WoRDS: Multilevel international protection, social rights, human rights, Social and Democratic State of law, social justice, International Covenant on Economic, Social and Cultural Rights, European Social Charter

SUMARIO

1. Introducción.

2. El Estado Social y Democrático de derecho en la actualidad: directrices para su restablecimiento y consolidación. 
3. La urgente necesidad de cumplimiento de los compromisos internacionales adquiridos y de incorporación de los retos pendientes.

3.1. La Organización de Naciones Unidas: el Pacto de Derechos Económicos Sociales y Culturales de 1966.

3.1.1. Procedimiento de Informes: las Observaciones finales de 2012 y 2018.

3.1.2. El Protocolo de comunicaciones individuales: las Comunicaciones núm. 2/2014 y 5/2015.

3.2. El Consejo de Europa: la Carta Social Europea de 1961 y sus Protocolos.

\subsubsection{El Procedimiento de Informes y las Conclusiones emitidas a España.}

3.2.2. El Protocolo de reclamaciones colectivas: la invocabilidad en las instancias judiciales españolas de las decisiones de fondo contra Grecia y Francia.

4. Reflexiones finales.

“(...) conviene llamar la atención sobre la paradoja que significa el enorme esfuerzo realizado por las Comunidades Autónomas al reformar sus Estatutos de Autonomía para incluir en ellos las referidas enumeraciones de derechos sociales (...) con el escaso interés que viene en España mostrando la instancia central por comprometerse, sin reservas, con la Carta Social Europea” TEROL BECERRA, $\mathbf{M}^{1}$

\section{Introducción ${ }^{2}$.}

El estudio que se realiza en las siguientes páginas tiene como finalidad contribuir a la consolidación y restablecimiento de los derechos y principios rectores que conforman el Estado social y democrático, que, tras el inicio de la crisis, se han visto afectados de forma considerable. A lo largo del mismo, se mostrará que los compromisos asumidos a nivel internacional, así como los estándares de protección de los derechos que recogen, son una

\footnotetext{
1 "La España de los derechos sociales en las Europas y las reformas estatutarias", En AA.VV. (Dir. Terol Becerra, M. y Jimena Quesada, L.), Tratado sobre protección de derechos sociales, Valencia, 2014. Tirant lo Blanch, págs. 164 y 165.

2 Principales abreviaturas utilizadas: art. (artículo), CE (Constitución Española), CDESC (Comité de Derechos Económicos, Sociales y Culturales), CEDH (Convenio Europeo para la Protección de los Derechos Humanos y de las Libertades Fundamentales), CEDS (Comité Europeo de Derechos Sociales), CSE (Carta Social Europea, para la versión revisada se utilizará la misma incluyendo en concreto esa referencia), ONU (Organización de Naciones Unidas), PIDESC (Pacto Internacional de Derechos Económicos, Sociales y Culturales), TEDH (Tribunal Europeo de Derechos Humanos), TC (Tribunal Constitucional), TSJ (Tribunal Superior de Justicia, por defecto Sala de lo social), UE (Unión Europea).
} 
de las vías apropiadas para la consecución de la libertad, igualdad, solidaridad y prosperidad.

Para ello, se procederá, en primer lugar, a delimitar su contenido a nivel constitucional y los problemas existentes en estos momentos en cuanto a su cuestionamiento o pérdida, tras las reformas legislativas adoptadas a partir de 2012, una parte todavía en vigor en el año 2019, y los preocupantes efectos que están produciendo en el conjunto de la ciudadanía, atendiendo a las reacciones provocadas.

En segundo lugar, teniendo presentes las obligaciones asumidas a nivel internacional, específicamente respecto a la Organización de Naciones Unidas y el Consejo de Europa, y el recurso cada más frecuente a los mecanismos de garantía a los que se dirigen los ciudadanos para su recuperación, se analizarán algunos de los incumplimientos detectados por los organismos de control y la necesidad de observarlos, exigencia de la Constitución española.

En tercer y último lugar, se examinarán los preocupantes resultados que se están produciendo frente a la renuencia de los poderes, legislativo, ejecutivo y, en algunas ocasiones, instancias superiores del judicial, a las violaciones de derechos sociales, que forman parte de los derechos humanos y la inexcusable e urgente necesidad de ocuparse de ellos como evidencia del interés de todas las instituciones que conforman el Estado en el respeto de los derechos humanos y, por derivación, de su implicación directa y prioritariamente en la recuperación de la democracia social que repercutirá positivamente en el funcionamiento y progreso del país con valores de libertad, igualdad y fraternidad.

\section{El Estado Social y Democrático de derecho en la actualidad: directrices para su restablecimiento y consolidación.}

La norma suprema que rige el ordenamiento jurídico español determina que "se constituye en un Estado social y democrático de Derecho, que propugna como valores superiores de su ordenamiento jurídico la libertad, la justicia, la igualdad y el pluralismo político” (art. 1 de la CE). A lo largo de su redacción, numerosas son las referencias que la complementan, en las que se muestran como postulados fundamentales que lo conforman, entre otros, el reconocimiento y ejercicio de los derechos humanos o la instauración y mantenimiento de un orden económico y social justo (Preámbulo).

Asimismo, en su articulado, dada la relevancia en la actualidad, son frecuentes las referencias a los derechos y cuestiones sociales, entre otras, por la vía de asegurar su protección (art. 39), la promoción de las condiciones favorables "para el progreso social y económico y para una distribución de la renta regional y personal más equitativa” (art. 40), el compromiso de mantener "un régimen público de Seguridad Social para todos los ciudadanos, que garantice la asistencia y prestaciones sociales suficientes ante situaciones de necesidad” (art. 41), la "salvaguardia de los derechos económicos y sociales de los trabajadores españoles en el extranjero” (art. 42) o la “suficiencia económica de la tercera 
edad [y la promoción de] su bienestar mediante un sistema de servicios sociales” (art. 50). Todas ponen de manifiesto el constitucionalismo social, en el que la solidaridad “constituye la matriz de los valores y derechos constitucionales más característicos (...) y propicia la vertebración del orden jurídico de toda la democracia”3.

El interés se sitúa en su asimilación a la idea de «grandeza», es decir, a la consecución de relevantes logros históricos e institucionales presididos por la responsabilidad del Estado frente a las necesidades vitales de los ciudadanos ${ }^{4}$, de manera que nadie quede desamparado.

Lamentablemente, en la actualidad, se ubica mayoritariamente en un nivel teórico del que España no es ajena, no reflejándose en el real. Se presencia un desmoronamiento de sus fundamentos y de esa magnitud que ha derivado, como advierte Supiot ${ }^{5}$, en una «miseria», en la que los recursos han ido disminuyendo e, incluso, desapareciendo. Una parte significativa de la población vive por debajo del umbral de pobreza (véase tabla $\mathrm{n}^{\circ}$ 1), más desde el inicio de la crisis y las consiguientes medidas de austeridad, que han tenido como objetivo prioritario la reducción y/o supresión de los derechos sociales, caracterizados, con frecuencia, como derechos secundarios frente a los civiles o políticos, no fundamentales ${ }^{6}$ así como de coste elevado $y$, en consecuencia, asociados únicamente a épocas de bonanza económica ${ }^{7}$, lejos de cualquier valoración como derechos humanos.

\footnotetext{
3 JIMENA QUESADA, L., «El tríptico liberal en el constitucionalista social», en Revista General de Derecho Público Comparado, 2017, n 20, pp. 2 y ss.

${ }^{4}$ SUPIOT, A., Grandeur et misère de l'Etat Social, Paris, 2013, Fayard, pp. 5 y 6.

${ }^{5}$ Ídem, pp. 8 y 9.

${ }^{6}$ Se trata de una apreciación que critica JIMENA QUESADA, y que en la actualidad debería estar superada, puesto que, “(...) atribuir el carácter de fundamental solamente a los derechos civiles y políticos en función de su nivel de garantías responde a una posición doctrinal sesgada asentada a su vez en una opción política restrictiva, tanto a escala nacional (el diseño del recurso de amparo en España) como internacional (mecanismo de peticiones individuales en el marco del Pacto de Derechos Civiles y Políticos de 1966), que se han visto superadas (así, la jurisprudencia social del Tribunal Constitucional español, o la más reciente introducción del sistema de denuncias individuales en el marco del Pacto de Derechos Económicos Sociales y Culturales)". "La armonización procesal europea en materia de derechos fundamentales tras el Tratado de Lisboa: el caso de los derechos sociales”, en AA.VV. (Dir. DE LA OLIVA SANTOS A. y CALDERÓN CUADRADO, M.P.), La armonización del Derecho Procesal tras el Tratado de Lisboa. Aranzadi, 2012, pp. 37 y 38. Propone el mismo autor, en cuanto a esta deficiencia, reformar la Constitución para "dejar clara la indivisibilidad de todos los derechos fundamentales, incluidos los sociales (...)”, en Devaluación y blindaje del Estado Social y Democrático de Derecho, Valencia, 2017, Tirant lo Blanch, p. 179 y ss.

${ }^{7}$ NIVARD, C., «Comité européen des droits sociaux (CEDS): Violation de la Charte sociale européenne par les mesures «anti-crise» grecques». Lettre Actualités-Droits-Libertes du CREDOF, 15 noviembre 2012, pp. 1 a 3 (https://revdh.files.wordpress.com/2012/11/lettre-adl-du-credof-15-novembre-20121.pdf) (última consulta 16/12/2018).
} 


\section{Personas en riesgo de pobreza o exclusión social (\%)}

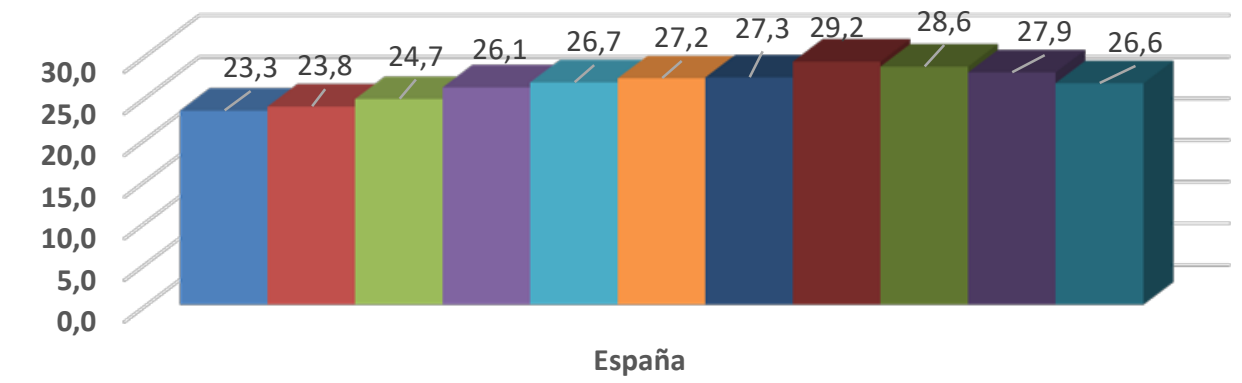

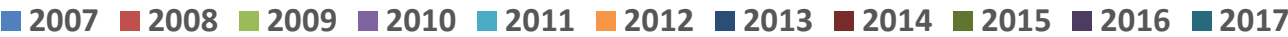

Tabla n $^{\circ} 1$ Elaboración propia Fuente: Eurostat http://appsso.eurostat.ec.europa.eu/nui/show.do?dataset=ilc_peps11\&lang=fr, última actualización 22/1/2019.

Explica el autor que el nuevo contexto internacional es la principal causa de ello, pero no la única, llegando a preguntarse hasta qué punto la globalización y, con ello, la desaparición de las distancias físicas, la libre circulación de mercancías y de capitales, que llevan unida la sobreexplotación de los recursos físicos no renovables y la exposición a los riegos sanitarios o ecológicos originados en el desarrollo técnico, no derivan en la necesidad de que el Estado social ceda ante otras modalidades de estructuración de las instituciones ${ }^{8}$. Sirva como constatación, entre otros, los datos del reciente informe de la ONU sobre el desarrollo de los recursos hídricos (2019) ${ }^{9}$ en el que más de 2000 millones de personas en el mundo carecen de acceso a los servicios básicos de agua y saneamiento y que esto provoca, además, discriminaciones de género, edad, condición religiosa, ética o lingüística.

Se contemplan situaciones difícilmente comprensibles en el siglo XXI y respecto de países que "presumen” de progreso y defensa de los derechos humanos como directriz de su actuación, pudiendo asimilarla más bien a la gestión de una empresa. La crisis griega es una claro ejemplo de cómo la asimilación "Estado-empresa” conduce a la ruina de la democracia y que el fomento de la desregulación que los Estados han materializado con las reformas laborales adoptadas, permite eludir precisamente "los diques" que se han ido construyendo para contener el poder económico ${ }^{10}$. La prueba del malestar de los ciudadanos ante la pérdida del estado bienestar es fácil encontrarla atendiendo a, por ejemplo, los estudios estadísticos o los últimos resultados electorales. Entre los primeros, la valoración de las instituciones muestra datos preocupantes, que, además, no apuntan

\footnotetext{
${ }^{8}$ SUPIOT, A., Grandeur et misère de l'Etat Social...op.cit., pp. 8 y 9. Un breve extracto de este estudio traducido al español en la Colección Informes $n^{\circ} 101$ (2014) de la Fundación $1^{\text {o }}$ de mayo, SUPIOT, A., Grandeza y miseria del Estado Social (traducción de JIMÉNEZ MANZORRO, P.A. y ARISTU MONDRAGÓN, J.), en http://www.1mayo.ccoo.es/nova/files/1018/Informe101.pdf, pp. 1 a 18.

${ }_{9}^{9}$ Accesible en https://unesdoc.unesco.org/ark:/48223/pf0000367304.

10 SUPIOT, A., "De la citoyenneté économique ", en Esprit, 2018, n 3, https://www.cairn.info/revueesprit-2018-3-p-52.htm, fecha de la consulta acceso 12/5/18), pp. 52 y ss.
} 
confianza de que cambiarán en un año (véase Tabla nº 2, además un $40 \%$ indica que la situación será igual y un 28,6\% incluso peor).

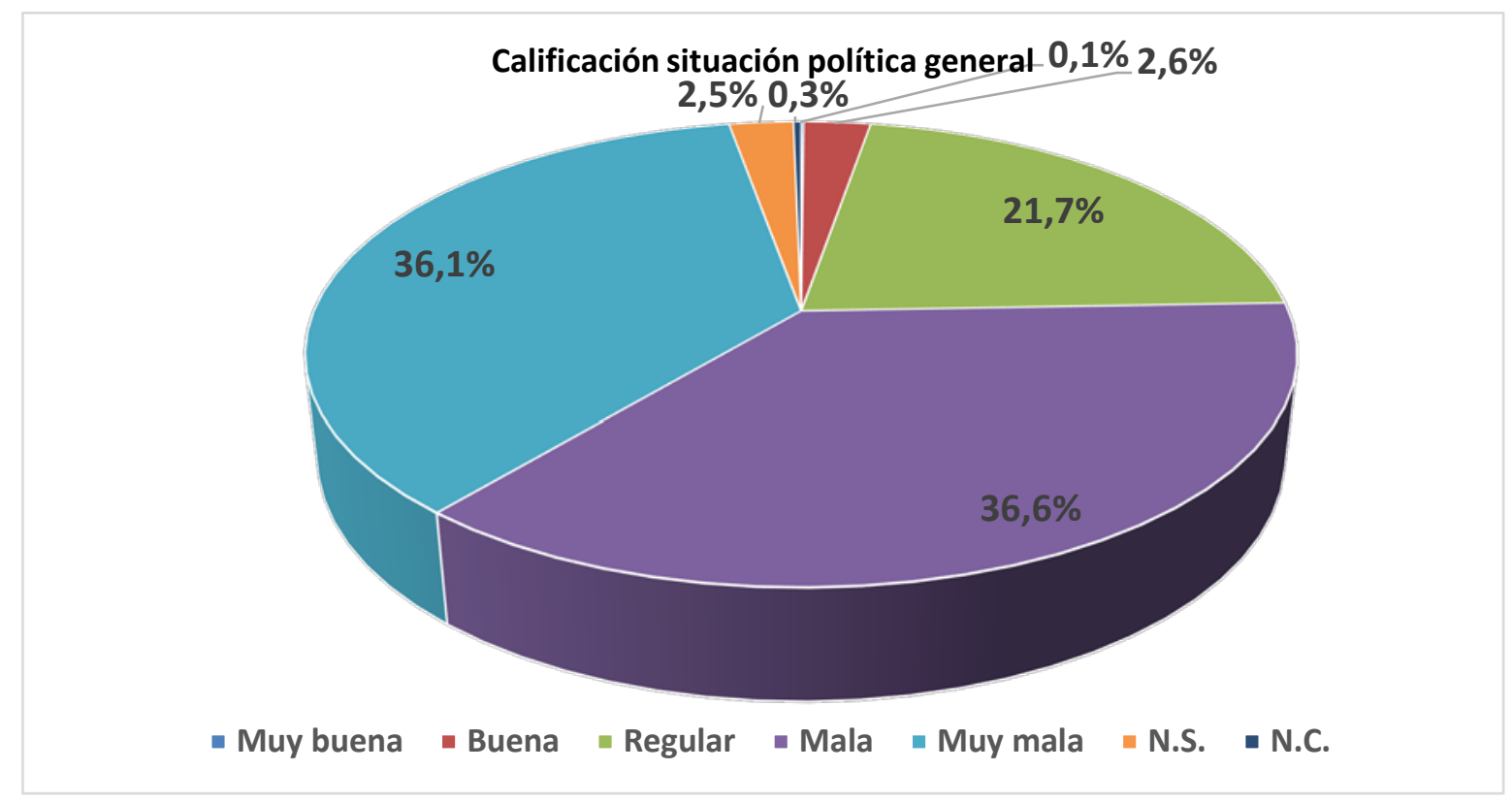

Tabla $\mathrm{n}^{\mathrm{0}} 2$ Elaboración propia Fuente: Barómetro CIS http://www.cis.es/cis/export/sites/default/Archivos/Marginales/3220_3239/3238/es3238mar.html, última actualización enero 2019

Por lo que se refiere a los segundos, se manifiesta con el rechazo a la Unión Europea, que acusa una problemática situación de desestructuración, déficit y deslegitimación ${ }^{11}$, evidenciada en situaciones como el Brexit o los preocupantes avances en las elecciones de algunos partidos políticos euroescépticos, antisistema, defensores del cierre de las fronteras o de la expulsión de inmigrantes. Es el caso de, entre otros, Brasil, Francia, Alemania o Italia. La idea de que esto es extraño a nosotros rápidamente se ha disipado

11 GRIMM, D., “Redonner à l’Union européenne une base politique légitime. Quand le juge dissout l'électeur ». $\quad$ Le Monde $\quad$ Diplomatique, $\quad$ Julio https://search.proquest.com/docview/1914002014?accountid=14777, pp. 1 a 5. Señala el autor que uno de los principales responsables de esta situación es el Tribunal de Justicia de la Unión Europea al elaborar una jurisprudencia “(...) fuera de todo control (...)”, declarando la aplicabilidad directa de los tratados y su primacía sobre todas las normas, incluidas las Constituciones, en suma, "la constitucionalización de los Tratados”. Las consecuencias son, entre otras, que este organismo los interpreta “(...) de manera más o menos independiente con respecto a la voluntad de sus firmantes, tomando como referencia una finalidad objetiva y sin prestar atención a la soberanía nacional”. Con ello, la intervención de los Estados para establecer un mercado común ya no es necesaria pues en el supuesto de que la norma de un Estado sea un obstáculo para su consecución, se declara inapropiada sin que pueda oponerse. Todo se residencia en este tribunal que “(...) persigue, con un celo considerable, un objetivo (la integración económica) al que subordina todos los demás intereses (...)”, emitiendo una jurisprudencia caracterizada por una interpretación extensiva que lo hacen erigirse “(...) más bien como un motor de la integración que como árbitro neutral entre la UE y los Estados miembros [produciendo como resultado] (...) un estado de la integración europea que nunca ha recibido el consentimiento de los ciudadanos y que estos no pueden cambiar aunque la rechacen”. Véase de forma más amplia "The Democratic Cost of Constitutionalisation: The European Case”, European Law Journal, 2015, n 4, pp. 471 a 473, en la que se apuntan las correcciones para hacer frente a este problema. 
tras las andaluzas, en el que la ultraderecha se ha adentrado en el Parlamento con 12 escaños.

La realidad apuntada, observada y soportada por la población, no debe ser ignorada ni mucho menos infravalorada.

Una de las directrices a seguir, a mi modo de ver fundamental, es la de observar los compromisos internacionales asumidos y, en consecuencia, los estándares de protección que ellos determinan. Su conveniencia deriva de que son el recurso de los ciudadanos, y también de la primera y segunda instancia judicial, para la recuperación de los derechos suprimidos o excesivamente limitados por las reformas legislativas de los últimos años. En este sentido, dos organizaciones internacionales, en concreto, la ONU y el Consejo de Europa, a través del Comité de Derechos Económicos, Sociales y Culturales y el Comité Europeo de Derechos Sociales respectivamente, están condenando a los países por las violaciones de su normativa reguladora, en suma, de los derechos humanos.

Así, a modo de ejemplo, son constantes las referencias y exigencias de cumplimiento del Pacto de Derechos Económicos, Sociales y Culturales de 1966 y de la Carta Social Europea de 1961 y sus Protocolos. Entre otros, el documento elaborado por tres de las ONG más importantes -Amnistía Internacional, Greenpeace y Oxfam Intermon-, Una reforma constitucional para blindar los derechos humanos, propone una modificación de 24 preceptos constitucionales que, conforme a Derecho internacional, "trate por igual todos los derechos humanos para todas las personas, pues los derechos son indivisibles y universales, sin clases ni jerarquías (...), gocen de mejores y mayores garantías de protección, (...), mejore la protección de los derechos a la vivienda y a la salud, regulando un contenido mínimo esencial, incorpore el derecho a la renta básica, para que sea un derecho de primera y para hacer frente al reto de la desigualdad, garantice un principio de «no regresividad» de los derechos y una financiación suficiente para hacerlos valer”, todo ello dirigido a que la crisis económica no sea “(...) excusa para poner las cuestiones económicas por delante de las personas"12.

De igual modo, ante las próximas elecciones europeas, se ha publicado un transcendente Manifiesto, Un nouveau modèle européen du travail ${ }^{13}$ elaborado por varios centenares de personalidades europeas del ámbito de la política, la investigación y sindicatos, que aconseja concebir un nuevo paradigma europeo, heredero del humanismo originario, que se convierta en una fuerza en la era de la globalización, fruto del cual se ha propuesto que, existiendo ya un texto en ese sentido, la Carta Social Europea sea reconocida y asumida verdaderamente en toda su magnitud por todos los Estados.

${ }^{12}$ En https://www.oxfamintermon.org/es/documentos/07/07/15/una-reforma-constitucional-para-blindartus-derechos, julio 2015, pp. 1 a 45.

${ }^{13}$ AA.VV., Remettre les salariés au coeur de l'Union européenne, Le Monde, 11 de mayo de 2018, https://search.proquest.com/docview/2036999601?accountid=14777. Véase también SICARD, "Pour une Europe sociale”, Les Echos, 1 juin 2018, pp. 1-3, https://search.proquest.com/docview/2048068138?accountid=14777 
Preferentemente demandada esta última, el origen radica en que se está en presencia del Tratado más importante e subrayo eficaz de defensa de los derechos sociales, calificación que resulta, entre otros, de su efecto directo en el ámbito jurisdiccional, no sólo en España sino también en otros países, caracterizada como la Constitución Social de Europa ${ }^{14}$. Así se puede constatar en Grecia con la sentencia $n^{0}$ 3220/2017 del Tribunal de Primera Instancia de El Pireo ${ }^{15}$, trascendental, histórica y sin precedentes al concluir de forma contundente que, tras la ratificación de la versión revisada, el despido sin causa es incompatible con el art. 24 de la CSE y, que, a partir de ese momento, los tribunales deberán, en cada supuesto que se les someta, verificar la existencia de un motivo y, en su ausencia, considerarlo como nulo y sin efectos por vulnerar la norma jerárquicamente superior y en Francia con el frente de algunos Conseils de Prud'hommes con idéntico alegato y el Convenio $\mathrm{n}^{\circ} 158$ de la OIT, en particular, Paris 22 de noviembre de 2018, Troyes 13 de diciembre de 2018, Amiens 19 de diciembre de 2018, Lyon 21 de diciembre de 2018 y 7 de enero de 2019, Angers 17 de enero de 2019, Grenoble 18 de enero de 2019, Tours 29 de enero de 2019, Agen 5 de febrero de 2019, Forbach s/d, febrero de 2019 y Dijon 19 de marzo de $2019^{16}$.

Esta referencia se convirtió en el núcleo del Proceso de Turín, lanzado por el Secretario General del Consejo de Europa en la Conferencia de Alto nivel que tuvo lugar en esa ciudad el 17 y 18 de octubre de $2014^{17}$. Se ha erigido en el estandarte de las manifestaciones que reclaman, entre otras, unas pensiones y salarios dignos, una renta mínima o el derecho a la salud así como la vía a utilizar por las referenciadas instancias judiciales para dejar sin efectos la normativa nacional que la vulnera. Se exigen los derechos que esos convenios reconocen y directamente atribuyen y, especialmente la CSE, se erige en "vector básico de referencia”" ${ }^{18}$.

\footnotetext{
${ }^{14}$ Referencia que se convirtió en el núcleo del Proceso de Turín, lanzado por el Secretario General del Consejo de Europa en esa ciudad el 17 y 18 de octubre de 2014. Rapport général Conférence à haut-niveau sur la Charte Sociale Européenne, pp. 1 a 240.

${ }^{15}$ Versión original en griego, véase la traducción inglesa realizada por PAP, S., DELIYANNI, C., TSIBOUKIS, C. Y GAVALAS, N., "Single-member First Instance Court of Piraeus 3220/2017”, Lex Social, revista de los derechos sociales, 2018, $\mathrm{n}^{\circ}$ 2, pp. 26 a 39 y el comentario de TSIMPOUKIS, C., “Some brief notes on decision n ${ }^{\circ}$ 3220/2017 of Piraeus' single-member Court of first instance”, Lex Social, revista de los derechos sociales, 2018, $\mathrm{n}^{\mathrm{o}} \quad 2$, pp. 18 a 25 , ambos en https://www.upo.es/revistas/index.php/lex_social/issue/view/206/showToc,

${ }^{16}$ Para un estudio más amplio, Mouly, J. "La barémisation des indemnités prud'homales: un premier pas vers l'inconventionnalité?", Droit Social, 2019, nº 2, pp. 2 a 12.

${ }^{17}$ Puede constatarse en las numerosas menciones, entre otras, "Toutes ces initiatives seront menées à bien pour que la Charte sociale puisse, dans l'intérêt de tous, toujours demeurer la Constitution sociale de l'Europe" o «Ce processus serait un pas déterminant pour la relance de la construction européenne car, comme d'aucuns l'ont indiqué de manière emblématique à l'occasion de la Conférence, il est essentiel que l'Europe prenne appui sur les valeurs fondamentales autour desquelles elle a vocation à rassembler les Etats et leurs citoyens - et tout spécialement sur les valeurs de la Charte, cette «Constitution sociale de l'Europe ». En Rapport général de la Conférence à haut-niveau sur la Charte sociale européenne, L'Europe repart à Turin, https://rm.coe.int/168048acf9, pp. 43 y 168.

18 JIMENA QUESADA, L., "La cuestión prejudicial europea ante planteamientos más que dudosos", UNED, Teoría y Realidad Constitucional, 2017, nº 39, p. 294.
} 
Si bien me limitaré a estas dos organizaciones, no han sido las únicas que han denunciado la inquietante realidad descrita pues considero relevante mencionar brevemente también la Organización Internacional de Trabajo y los cuatro últimos estudios publicados que denuncian equivalentes situaciones y la necesidad de acometer medidas. Así, los Informes sobre la Protección Social 2017-2019, Perspectivas sociales y del empleo en el mundo: Tendencias 2019, Trabajar para un futuro más prometedor, 2019 y el elaborado en relación a los Salarios 2018/2019 muestran datos preocupantes actuales y previstos. Se afirma que el derecho humano a la seguridad social sigue sin hacerse efectivo para la mayoría de la población mundial (el 55\% -unos 4.000 millones de personas- no tienen protección social, lo que unido a los que sólo tienen cobertura parcial asciende al 71\% 5.200 millones de personas-, con la consiguiente exposición a la pobreza, enfermedades, desigualdades y exclusión social en todo el ciclo de vida), siendo preciso destacar que el derecho a la salud no es una realidad en muchos lugares del mundo, en especial en las zonas rurales, donde el 56\% de la población carece del mismo.

En cuanto al número total de desempleados a nivel mundial en el año 2018 se sitúa en más de 172 millones, previéndose que aumente hasta 174 millones en 2020 (de esas cifras, más del $60 \%$ se focaliza en jóvenes), matizando la generalización de los déficits de trabajo decente, que se concretan en que más de una cuarta parte de los trabajadores de países de ingreso bajo y de ingreso mediano-bajo viven en situación de pobreza extrema o moderada (300 millones de trabajadores) y que muchos de estos se ven abocados a aceptar puestos de trabajo informales y mal remunerados (2.000 millones de personas basan su sustento en esa economía).

Se incorporan en los análisis los datos de siniestralidad, de los que se concluye que 2,78 millones de personas fallecen anualmente como consecuencia de accidentes de trabajo o de enfermedades profesionales y tienen escaso o nulo acceso a la protección social y a los derechos laborales, sin olvidar, el no menos significativo del envejecimiento de la población, que inevitablemente provocará un aumento del promedio de la edad de quienes integran la población activa, pondrá en jaque la capacidad de los trabajadores para mantenerse al ritmo de las innovaciones y los cambios estructurales en el mercado de trabajo, a la vez que incidirá en la sostenibilidad de los sistemas de prestaciones sociales.

Desde el momento en que todo el marco jurídico internacional forma parte del ordenamiento español, como así se determina en la configuración del sistema de fuentes, y expresamente referencia la Carta Magna, en los arts. 10.2 ("Las normas relativas a los derechos fundamentales y a las libertades que la Constitución reconoce se interpretarán de conformidad con la Declaración Universal de Derechos Humanos y los tratados y acuerdos internacionales sobre las mismas materias ratificados por España”) y 96 (“Los tratados internacionales válidamente celebrados, una vez publicados oficialmente en España, formarán parte del ordenamiento interno. Sus disposiciones sólo podrán ser derogadas, modificadas o suspendidas en la forma prevista en los propios tratados o de acuerdo con las normas generales del Derecho internacional”), desarrollados por la Ley 
25/2014, de 27 de noviembre, de Tratados y otros Acuerdos Internacionales ${ }^{19}$, se deben respetar y asumir como ineludible muestra de la seguridad jurídica.

Por ello, se proceden a examinar los instrumentos normativos de dos organizaciones supranacionales de referencia, algunas de las condenas que España ha recibido, con la finalidad de que sean observadas, y los retos pendientes que necesariamente se deben acometer. Así, se fortalecería el Estado Social, los valores democráticos, se corregiría una de los mayores e inadmisibles déficits democráticos que tenemos frente la gran mayoría de países europeos y se incrementaría la confianza de la sociedad en la justicia social.

\section{La urgente necesidad de cumplimiento de los compromisos internacionales adquiridos y de incorporación de los retos pendientes.}

En los siguientes apartados se proceden a analizar dos de los tratados más importantes en materia de derechos sociales respecto de los que nuestro país tiene en la actualidad obligaciones pendientes que asumir, originadas en las condenas que ha recibido, así como insoslayables desafíos que asumir para reforzar su legitimidad democrática.

En particular, me estoy refiriendo al Pacto de Derechos Económicos, Sociales y Culturales de 1966 y a la Carta Social Europea de 1961, completada por protocolos accesorios y enmienda. Presentan en común que forman parte del orden jurídico internacional contribuyendo al mismo, además de la denominación de Comité de las instituciones que aclaran su contenido y aseguran su efectividad a través de la verificación de su cumplimiento -CDESC y CEDS- ${ }^{20}$, que es utilizada por sectores doctrinales y judiciales para subestimar su naturaleza jurídica así como del carácter vinculante de sus pronunciamientos $^{21}$. Así, los responsables gubernamentales españoles son una prueba de ello, teniendo uno de los ejemplos en las respuestas al Cuestionario relativo a las buenas

\footnotetext{
${ }^{19}$ Complementadas, entre otras, por el art. 1.5 del CC ("Las normas jurídicas contenidas en los tratados internacionales no serán de aplicación directa en España en tanto no hayan pasado a formar parte del ordenamiento interno mediante su publicación íntegra en el «Boletín Oficial del Estado”).

${ }^{20}$ AKANDJI-KOMBE, J.F., "Charte Sociale Européenne et Pacte International sur les droits économiques, sociaux et culturels ", en AA.VV (ed. ALIPRANTIS, A.), Les droits sociaux dans les instruments européens et internationaux. Défis à l'échelle mondiale, Bruxelles, 2008, Bruylant, p. 220 a 223. Añade el autor que el proceso de convergencia entre los dos textos es constante, si bien presentan también diferencias, entre otras, que la CSE dedica cada uno de sus artículos a un derecho concreto mientras que el PIDESC los reagrupa dentro uno, la existencia de derechos protegidos por el primero y no por el segundo (discapacitados, trabajadores migrantes y sus familias, representantes de los trabajadores o personas de edad avanzada), además de la mayoría de derechos añadidos por la versión revisada de la CSE, igualdad de oportunidades, protección por despido o en caso de insolvencia del empresario, información y consulta en los supuestos de despido colectivo, etc. En términos similares, LÓPEZ MARTIN, A.G., "La protección internacional de los derechos sociales. A propósito de la ratificación española del Protocolo Facultativo del Pacto de Derechos económicos, sociales y culturales de 2008”, en Foro, Nueva Época, 2001, n 13, p. 35.

${ }^{21}$ Muy crítica se muestra con este órgano Hachez, I., "Le Comité Européen des droits sociaux confronté à la crise financière grecque : des décisions osées mais inégalement motivées », Revue de Droit Social, 2014, $n^{\circ}$ 3, pp. 252 y ss. http://www.uac.bj/web/fileadmin/document_cat/2014/3/TSR_2014_3-A.pdf (última consulta 22/2/2019) y, entre otras, la STSJ de Castilla y León/Valladolid de 25 de marzo de 2015, Rec. $60 / 2015$
} 
prácticas sobre la aplicación de los derechos sociales a nivel nacional que efectuó el grupo de redacción sobre los derechos sociales (CDDH-SOC) ${ }^{22}$, publicado el 12 de diciembre de 2017. En el mismo manifestaron que el país “cumple” el Tratado y que las objeciones se derivan de la interpretación que realiza el CEDS, “(...) que va más allá del texto de la Carta y la de la interpretación anexa a la misma, incrementando las obligaciones y creando inseguridad jurídica para los Estados que lo han ratificado”. Me remito al punto 3.2.1 de este estudio en el que se puede verificar la veracidad y consistencia de la afirmación indicada con las conclusiones que acaba de pronunciar este organismo, que se adicionan a las que lleva emitiendo en anteriores exámenes efectuados condenando directamente a nuestro país.

\subsection{La Organización de Naciones Unidas: el Pacto de Derechos Económicos Sociales y Culturales de 1966.}

España ingresó en la Organización de Naciones Unidas el 14 de diciembre de 1955, junto con otros quince países. Lógicamente, la primera consecuencia que resulta es la de respetar sus principios configuradores, materializados y desarrollados a través de su normativa. Si bien este acontecimiento tuvo lugar hace muchos años y ha sido continuado por la ratificación de convenios adoptados por la misma, puede completarse con otras referencias más recientes, como por ejemplo, la elección por unanimidad el 7 de mayo de 2018 para ocupar una de las cuatro vicepresidencias del Consejo de Derechos Humanos de esta institución, en concreto, la correspondiente al grupo regional de Países Occidentales y otros, demostrando con ello, como literalmente determina la nota de prensa oficial ${ }^{23}$, "el reconocimiento internacional del compromiso de los poderes públicos y de la sociedad española con los Derechos Humanos”.

Estas actuaciones son merecedoras de la correspondiente valoración positiva, si bien, menos de la que en un principio se pudiera pensar, desde el momento en que se limitan a ser formales, difundidas en los medios de comunicación, pero que no son continuadas de hechos que permitan constatar su efectividad, es suma, el respeto de los derechos humanos se limita al plano teórico.

Así, con carácter general, el Experto Independiente de la ONU en el Informe sobre Las consecuencias de la deuda externa y las obligaciones financieras internacionales conexas de los Estados para el pleno goce de todos los derechos humanos, sobre todo los derechos económicos, sociales y culturales (18 de julio de 2018), complementado con el emitido previamente ${ }^{24}$, insiste en la afectación y repercusión negativa de las políticas de

22 https://rm.coe.int/reponses-au-questionnaire-relatif-aux-bonnes-pratiques-sur-la-mise-en-/16807762ac (último acceso 9/3/19)

23 http://www.spainun.org/2018/05/espana-elegida-vicepresidenta-en-el-consejo-de-derechos-humanos/ (último acceso 16/2/2019)

$24 \quad$ Bohoslavsky, J.P, https://documents-ddsny.un.org/doc/UNDOC/GEN/N18/229/07/PDF/N1822907.pdf?OpenElement $\quad$ https://documents-ddsny.un.org/doc/UNDOC/GEN/G17/364/96/PDF/G1736496.pdf?OpenElement (último acceso 16/2/2019), pp. 1 a 27 y 8 a 20. BOHOSLAVSKY, J.P, "Informe del Experto Independiente sobre las consecuencias de 
consolidación fiscal en los derechos humanos de las personas en situaciones de mayor vulnerabilidad, además de que la mayor parte de ellas no se han concebido ni ejecutado de manera que promuevan o salvaguarden los derechos humanos, $\mathrm{y}$, mucho menos, teniendo en cuenta sus efectos relacionados con el género.

Al mismo tiempo, ni siquiera, han resuelto los problemas por los que se adoptaron ya que, por el contrario, han contribuido a prolongar la crisis económica y han supuesto una amenaza para los derechos humanos mayor que la que planteaba la propia crisis, acrecentando la exclusión social, el número de personas sin hogar o el desempleo de larga duración.

Con base en las obligaciones y las responsabilidades existentes en materia de derechos humanos de los Estados y otros agentes se han presentado públicamente en marzo de 2019 unos Principios rectores relativos a las evaluaciones de los efectos de las reformas económicas en los derechos humanos ${ }^{25}$, en los que reitera los compromisos contraídos. En particular, se emiten veintidós que resumidamente consisten en la necesidad de respetar, proteger y hacer efectivos todos los derechos humanos en la formulación de políticas económicas y en la gestión de los asuntos fiscales, el deber de hacer evaluaciones para evaluar y abordar cualquier incidencia previsible de las políticas económicas en los derechos humanos, la imposibilidad de justificar la inobservancia o eludir responsabilidades en determinados períodos, la adopción de cualquier decisión o medida económica teniendo presente los tratados internacionales fundamentales de derechos humanos, así como su interpretación autorizada en las observaciones generales, declaraciones, cartas abiertas, decisiones, observaciones finales y recomendaciones formuladas por los órganos de supervisión de los tratados, la indivisibilidad, realización progresiva e interdependencia de todos los derechos humanos $\mathrm{y}$, por último, la prohibición de regresión de cualquier propuesta económica en la realización de los derechos económicos, sociales y culturales considerándose una violación prima facie de esos derechos.

Esta valoración no es ajena a España y es fácilmente trasladable recurriendo a los últimos datos que reflejan, por ejemplo, la considerable desigualdad y las diferencias en cuanto a la distribución de la renta frente a la media de la UE, resultando un malestar social que, en estos momentos, presenta uno de sus puntos más álgidos (véase Tabla ${ }^{0}$ 3).

\footnotetext{
la deuda externa y las obligaciones financieras internacionales conexas de los Estados para el pleno goce de todos los derechos humanos, sobre todo los derechos económicos, sociales y culturales. Elaboración de unos principios rectores para evaluar el impacto de las políticas de reforma económica en los derechos humanos", Consejo de Derechos Humanos $37^{\circ}$. https://documents-ddsny.un.org/doc/UNDOC/GEN/G17/364/96/PDF/G1736496.pdf?OpenElement (último acceso 16/2/2018), pp. 8 a 20.

${ }^{25}$ Consejo de Derechos Humanos $40^{\circ}$ período de sesiones 25 de febrero a 22 de marzo de 2019, https://documents-dds-ny.un.org/doc/UNDOC/GEN/G18/443/55/PDF/G1844355.pdf?OpenElement
} 


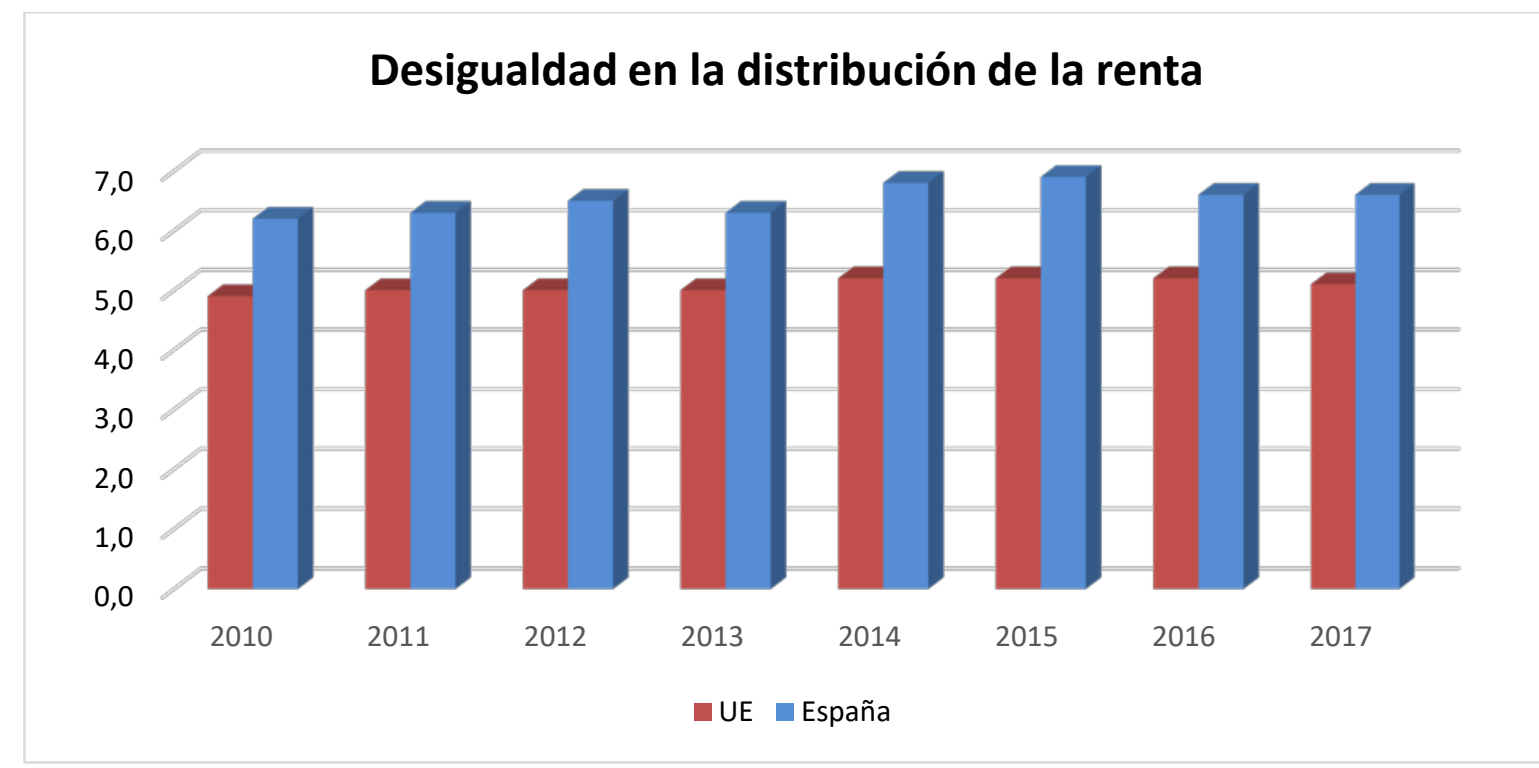

Tabla $\mathrm{n}^{0} \quad 3$ Elaboración propia Fuente: Eurostat, Inequality of income distribution, http://ec.europa.eu/eurostat/en/web/products-datasets/-/TESPM151, útima actualización: 15/01/19.

Nuestro país ha suscrito los dos Tratados más relevantes de esta organización, por un lado, el Pacto de Derechos Civiles y Políticos, y, por otro lado, el Pacto Internacional de Derechos Económicos, Sociales y Culturales de 16 de diciembre de 1966, firmados el 28 de septiembre de 1976 y ratificados el 27 de abril de 1977 (BOE de 30 de abril). Centrándome, como he apuntado, en el segundo, cada uno de los Estados Partes se compromete “(...) a adoptar medidas, tanto por separado como mediante la asistencia y la cooperación internacionales, especialmente económicas y técnicas, hasta el máximo de los recursos de que disponga, para lograr progresivamente, por todos los medios apropiados, inclusive en particular la adopción de medidas legislativas, la plena efectividad de los derechos aquí reconocidos” (art. 2).

El precepto es claro en este sentido, y para disipar cualquier duda el CDESC emitió la Observación General 3, sobre La índole de las obligaciones de los Estados Partes 14/12/90, en la que categóricamente determinó que incluye tanto "obligaciones de comportamiento como obligaciones de resultado”, y que, si bien en muchos casos las medidas legislativas son deseables e incluso indispensables, estas no agotan por sí mismas las obligaciones de los Estados. Cada país, “(...) debe decidir por sí mismo qué medios son los más apropiados de acuerdo con las circunstancias y en relación con cada uno de los derechos contemplados, [pero] la "propiedad" de los medios elegidos no siempre resultará evidente, siendo el Comité el que finalmente determinará si se han adoptado o no las apropiadas (...)”, entre las que se incluyen, además de las legislativas, la de "ofrecer recursos judiciales en lo que respecta a derechos que, de acuerdo con el sistema jurídico nacional, puedan considerarse justiciables” así como las de carácter 
administrativo, financiero, educacional y social, siempre que, "todos los derechos humanos se respeten" 26 .

Con ella, además se rebatió el argumento invocado por los países en cuanto a predicar el carácter no vinculante del PIDESC con el pretexto de la cláusula de progresividad del art. 2.1 ("Cada uno de los Estados Partes en el presente Pacto se compromete a adoptar medidas, tanto por separado como mediante la asistencia y la cooperación internacionales, especialmente económicas y técnicas, hasta el máximo de los recursos de que disponga, para lograr progresivamente, por todos los medios apropiados, inclusive en particular la adopción de medidas legislativas, la plena efectividad de los derechos aquí reconocidos”) y de esta forma sortear las obligaciones, manifestando que no son obligaciones de naturaleza programática y diferida sino de aplicación inmediata, es decir, revisten carácter de self-executing, siendo rotundo al señalar que “(...) si bien la plena realización de los derechos pertinentes puede lograrse de manera paulatina, las medidas tendentes a lograr este objetivo deben adoptarse dentro de un plazo razonablemente breve tras la entrada en vigor del Pacto para los Estados interesados. [Éstas] deben ser deliberadas, concretadas y orientadas lo más claramente posible hacia la satisfacción de las obligaciones reconocidas en el Pacto" y con ello "difícilmente sostenible sugerir que las disposiciones indicadas son intrínsecamente no autoejecutables”27.

Se trata de un elemento en el que me detendré brevemente al ser una cuestión muy controvertida, principalmente cuando la normativa no es de la UE, al incorporarse al marco jurídico por una vía diferente, más lenta pero que finaliza con esa integración, en el mismo nivel, es decir, carente de jerarquía respecto de su homónima.

Con carácter general, la aplicación directa de los convenios internacionales viene condicionada, según la jurisprudencia, en primer lugar, por su suscripción y publicación oficial en el BOE, y, en segundo lugar, por la entrada en vigor y la naturaleza selfexecuting de sus disposiciones ${ }^{28}$, es decir, “que su redacción sea lo suficientemente precisa para consentir esa aplicación directa sin necesidad de un ulterior desarrollo legal

\footnotetext{
${ }^{26}$ Muy relevante es la Declaración de 29 de marzo de 2017 del CDESC en la que, en cuanto a los defensores de los derechos humanos (ONG, entre otras) y su exposición a riesgos y amenazas, comunica a los Estados “(...) la responsabilidad de garantizar la protección efectiva (...) frente a todo tipo de abusos, violencia y represalias de que puedan ser objeto en el desempeño de su labor destinada a promover a efectividad de esos derechos".

${ }^{27}$ Véase MANERO SALVADOR, A., "El incumplimiento de las obligaciones internacionales en materia de derechos económicos, sociales y culturales en el contexto de la crisis económica internacional”, en Estudios de Progreso Fundación Alternativas, 2013, $\mathrm{n}^{\circ} \quad 75$, pp. 21 a 23 , en http://www.fundacionalternativas.org/public/storage/actividades_descargas/0bf7f9485bab622b6d1cd7b8f 9d1f3c5.pdf (último acceso 3/12/18).

${ }^{28}$ Los términos aplicabilidad o efecto directo, así como self-executing se utilizarán de forma equivalente, debiendo tener presente que al estudiar la misma situación en otros países éstos pueden tener diferente significación, si se compara la lengua francófona con la anglófona. Véase TAXIL, B., «Méthodes d'integration du droit international en droits internes», Ponencia impartida en le Troisième Congrès de l'Association des Hautes Juridictions de Cassation des pays ayant en partage l'usage du français, «Internationalisation de la justice, internationalisation du droit», Otawa, 21 al 23 junio 2010 http://www.ahjucaf.org/IMG/pdf/Internationalisation_du_droit.pdf (última consulta 31/8/2018), p. 189.
} 
y reglamentario que represente la voluntad de los Estados contratantes" (SSTS, Contencioso-administrativo, de 7 octubre 1997, Rec. 818/1993, 10 de marzo de 1998, Rec. 3048/1992 o 22 de abril de 2010, Rec. 506/2007).

En el ordenamiento español, una interpretación coherente del art. 96.1 de la CE, en combinación con el art. 10.2, obliga a incorporar los tratados en nuestro marco normativo, precepto que se traduce en el reconocimiento del aforismo "pacta sunt recipienda", conectado con el art. 26 de la Convención de Viena sobre el Derecho de los Tratados de 23 de mayo de 1969, relativo a la observancia de los tratados ${ }^{29}$ y los arts. 23.3, 28 y 29 de la Ley 25/2014, de 27 de noviembre, de Tratados y otros Acuerdos Internacionales. Ello ineludiblemente implica que, con posterioridad al texto constitucional, forman parte del ordenamiento interno de forma automática, previa su inserción oficial, excluyéndose el mecanismo dualista de la transformación o recepción especial del derecho internacional.

Es clara desde hace tiempo la jurisprudencia que ha señalado que “(...) frente a la antigua doctrina dominante entre los internacionalistas clásicos, que sostenían el criterio de que los Tratados y Convenios Internacionales no eran en sí mismo fuente creadora de nuestro Derecho interno, sino una regla vinculante entre los Estados signatarios, que para dotarla de fuerza de obligar respecto de sus ciudadanos necesitaba un acto jurídico interno adecuado, la práctica, en función de las relaciones internacionales y la consagración plena de las Organizaciones supranacionales, ha llevado al reconocimiento de los Tratados y su aplicación entre los Estados signatarios como Derecho interno, cumplidas las formalidades previstas para formar parte de nuestro Derecho jurídico interno, sin necesidad de que se produzca ninguna otra disposición confirmadora de lo que ya pasó a ser Derecho interno" (STS, Contencioso-administrativo, de 7 de octubre de 1997, Rec. 818/1993).

De hecho, aún en el caso de tratarse de un convenio con una redacción que no sea suficientemente precisa, se ha señalado que no le convierte en un texto programático, que se limite a contener orientaciones más o menos precisas en relación con una materia puesto que los términos que suelen utilizar en cuanto a los compromisos que los Estados asumen en orden a garantizar, prohibir, castigar o enjuiciar conllevan que las actuaciones y regulaciones contrarias vulneren una norma integrada en el sistema de fuentes (STS, Contencioso-administrativo, de 22 de abril de 2010, Rec. 506/2007).

A mi juicio es irrefutable que existen suficientes fundamentos jurídicos para materializar la efectividad de los derechos y las garantías internacionales respecto de los casos concretos que se pueden plantear en cualquier instancia estatal, incluida la sede judicial,

\footnotetext{
29 "Pacta sunt servanda. Todo tratado en vigor obliga a las partes y debe ser cumplido por ellas de buena $f e$ ". Ratificada por España por el Instrumento de adhesión de 2 de mayo de 1972 (BOE de 13 de junio de 1980).
} 
es decir, su justiciabilidad ${ }^{30}$. Ahora bien, esta afirmación que, en principio, no debería presentar problemas, tiene numerosas resistencias, sobre todo en materia de derechos sociales. Como se ha apuntado, la habitual firma de un tratado, que suele ir acompañada de la correspondiente publicidad con la que demostrar el impulso internacional del país, a partir del momento de asumir las consecuencias de un posible incumplimiento es cuando aparecen los cuestionamientos y las teorías que giran en torno a que los tratados son meros principios inspiradores, con lo que la pretendida internacionalización debe ceder, en esas situaciones, a las fronteras estatales ${ }^{31}$, quedando, los derechos y garantías asumidos en un plano formal y no real, que es dónde debería desplegar sus efectos.

Una vez se ha aclarado el efecto directo y vinculante de PIDESC, así como, por derivación, de la CSE, objeto de estudio posteriormente, a lo largo de su articulado (31 preceptos), se reconocen derechos como al trabajo, al goce de condiciones de trabajo equitativas y satisfactorias (remuneración mínima, salario equitativo, condiciones de existencia dignas, seguridad e higiene...), a un nivel de vida adecuado para sí y su familia, incluso alimentación, vestido y vivienda adecuados o a una mejora continua de las condiciones de existencia, derecho de huelga y sindicación, etc. (arts. 6 y ss.).

El control de su cumplimiento lo efectúa, como se ha apuntado, el CDESC por dos vías, una general aplicable a cualquier Estado que suscriba el tratado, el procedimiento de informes, y, otra específica, más reciente, que sólo se puede ejecutar respecto a los que han suscrito el protocolo específico que la regula, que serán analizadas a continuación con referencia a los incumplimientos detectados, demostrando que, en nuestro país, en la actualidad se violan derechos humanos cuyo cumplimiento es exigido por la sociedad.

\subsubsection{Procedimiento de Informes: las Observaciones finales de 2012 y 2018}

De conformidad con lo dispuesto en el art. 16 del PIDESC, "los Estados Partes (...) se comprometen a presentar informes sobre las medidas que hayan adoptado, y los progresos realizados, con el fin de asegurar el respeto a los derechos reconocidos en el mismo”, inicialmente cada dos años, con posterioridad cada cinco. En cuanto a su sustanciación, se transmiten copias al Consejo Económico y Social para que las examine, a los órganos especializados y a las partes pertinentes de estos en la medida en que estos total o parcialmente tengan relación con materias que sean de su competencia ${ }^{32}$. Tras su examen

\footnotetext{
30 Entendida, como apunta MILÁ MORENO, como la "capacidad de ser invocable ante los órganos jurisdiccionales o cuasijurisdiccionales para obtener la protección de los mismos ante un caso concreto", en "El Pacto Internacional de derechos económicos, sociales y culturales”, AA.VV. (Dir. GÓMEZ ISA, F.), La protección internacional de los derechos humanos en los albores del siglo XXI, Bilbao, 2004, Universidad de Deusto, pp. 192 y 193.

${ }^{31}$ FALGUERA BARÓN, M.A., «La normativa de la OIT y su translación en el ordenamiento interno por la Sala de los Social del Tribunal Supremo. Algunas reflexiones de futuro tras la última reforma laboral». Iuslabor, 15 de septiembre de 2012, http://www.iuslabor.org/articles-de-dret-laboral-i-seguretatsocial/dret-laboral-i-seguretat-social/extincio-contracte-de-treball/, p. 2

32 Sobre el mismo véase el estudio más amplio de RUILOBA ALVARIÑO, J., "Los Pactos Internacionales de las Naciones Unidas de 16 de diciembre de 1966”, En AA.VV., (Coord. FERNÁNDEZ CASADEVANTE ROMANÍ, C.), Derecho internacional de los derechos humanos, $2^{\mathrm{a}}$ ed., Madrid, 2007, Dilex, pp. 156 y ss.
} 
y valoración, el CDESC emite unas, las Observaciones finales instando a las autoridades a corregir los incumplimientos que detecte.

En particular, en el Quinto informe periódico en cuanto a España ( $48^{\circ}$ período de sesiones, 30 de abril a 18 de mayo de $2012^{33}$ ), expresamente le efectuó las siguientes:

a) Que, en virtud del principio de indivisibilidad, universalidad e interdependencia de los derechos humanos, adopte las medidas legislativas pertinentes para garantizar a los derechos económicos, sociales y culturales un nivel de protección análogo al que se aplica a los derechos civiles y políticos, recomendando que tome las medidas adecuadas para asegurar la plena justiciabilidad y aplicabilidad de todas las disposiciones del Pacto por los tribunales nacionales.

b) Que garantice que todas las medidas de austeridad adoptadas identifiquen el contenido mínimo esencial de todos los derechos del PIDESC, y que tome todas las medidas apropiadas para proteger este contenido esencial en cualquier circunstancia, especialmente para las personas y los grupos desfavorecidos y marginados. Para ello le remite a la Carta abierta sobre los derechos económicos, sociales y culturales en el contexto de la crisis económica y financiera de 16 de mayo de $2012^{34}$ en la que subrayó que, en virtud del PIDESC, todos los Estados partes deben evitar en todo momento la adopción de decisiones que puedan conducir a la negación o violación de los derechos económicos, sociales y culturales, puesto que, además de ser contrario a sus obligaciones, puede conducir a la inseguridad social y la inestabilidad política y tener impactos negativos significativos.

Si bien, las crisis económicas y financieras y la falta de crecimiento pueden impedir la progresiva realización progresiva de los derechos económicos, sociales y culturales y conducir a la regresión en el disfrute de esos derechos, no está permitido "actuar en violación de sus obligaciones”, teniendo que cumplir cualquier cambio de política o ajuste los siguientes requisitos:

-En primer lugar, debe ser una medida temporal, es decir, sólo para el período de crisis.

-En segundo lugar, debe ser necesaria y proporcionada, en el sentido de que la adopción de cualquier otra política o una omisión, serían más perjudiciales para los derechos económicos, sociales y culturales.

-En tercer lugar, no debe ser discriminatoria y debe comprender todas las medidas posibles, incluidas las medidas fiscales, para apoyar las transferencias sociales para mitigar las desigualdades que pueden crecer en tiempos de crisis y para garantizar que los derechos de las personas $y$ grupos desfavorecidos $y$ marginados no son desproporcionadamente afectados.

\footnotetext{
$3348^{\circ}$ período de sesiones. 30 de abril a 18 de mayo de 2012 (E/C.12/ESP/CO/5).

${ }^{34}$ http://www2.ohchr.org/english/bodies/cescr/docs/LetterCESCRtoSP16.05.12.pdf último acceso 7/12/18.
} 
-En cuarto lugar y último lugar, debe identificar el contenido mínimo esencial de los derechos o de un mínimo de protección social.

c) Que asegure el derecho a la asistencia sanitaria universal, de conformidad con la Observación general n. ${ }^{\circ} 14$ (2000) sobre el derecho al disfrute del más alto nivel posible de salud (art. 12 del PIDESC) y con el principio de universalidad de las prestaciones sanitarias. Tras la modificación legislativa que se realizó por el anterior gobierno (Real Decreto-Ley 16/2012, de 20 de abril, de medidas urgentes para garantizar la sostenibilidad del Sistema Nacional de Salud y mejorar la calidad y seguridad de sus prestaciones), se excluyó del mismo a los inmigrantes en situación irregular, condenándose al vulnerar el precepto mencionado.

Brevemente indicaré que si esa modificación legislativa era reprobable, más lo eran los argumentos que el gobierno de esos momentos alegó para su introducción y mantenimiento, que residenció en afrontar el "turismo sanitario" 35 y que el colectivo pasaba a ser protegido por las Comunidades Autónomas, en el marco del ejercicio de sus competencias.

El primero era insostenible si se atendía a los estudios realizados en, por ejemplo, el Informe de Médicos del Mundo Access to healthcare for people facing multiple vulnerabilities in health in 31 cities in 12 countries (2016), en el que indica que, entre los motivos de las personas que migran a Europa, únicamente el 3\% lo hace por motivos de salud $^{36}$. Y, en cuanto al segundo, se obvió referenciar la interposición de recursos contra esas normas autonómicas ante el Tribunal Constitucional ${ }^{37}$, que, además, fueron resueltos favorablemente para el Gobierno ${ }^{38}$.

Afortunadamente, el cambio de gobierno en el año 2018 conllevó el restablecimiento de esa asistencia sanitaria universal con el Real Decreto-ley 7/2018, de 27 de julio ${ }^{39}$.

\footnotetext{
${ }^{35}$ La última se puede encontrar en la respuesta de los representantes del Gobierno al Comité de Derechos Económicos, Sociales y Culturales en el examen del sexto informe periódico de España sobre la aplicación de las disposiciones del Pacto Internacional de Derechos Económicos, Sociales y Culturales, 22 de marzo de 2018 (http://www.ohchr.org/EN/NewsEvents/Pages/DisplayNews.aspx?NewsID=22888\&LangID=E, último acceso 1/11/2018).

36 https://mdmeuroblog.files.wordpress.com/2016/11/observatory-report2016_en-mdm-international.pdf, p. 17.

${ }^{37}$ Entre otras, el País Vasco con el Decreto 114/2012, de 26 de junio, sobre régimen de las prestaciones sanitarias del Sistema Nacional de Salud, la Comunidad Valenciana, con el Decreto Ley 3/2015, de 24 de julio, del Consell, por el que regula el acceso universal a la atención sanitaria, Aragón, el 7 de agosto de 2015 publicó una Instrucción por la que se regula el acceso a la asistencia sanitaria para las personas extranjeras sin recursos económicos suficientes ni cobertura de asistencia sanitaria del Sistema nacional de salud o Cantabria con la Orden SAN/38/2015, de 7 de agosto. La STSJ, Contencioso-administrativo, de 30 de mayo de 2016, Rec. 305/2015, anuló la última de esas normas y recientemente las sentencias del TC 134/2017, de 16 de noviembre de 2017 y 145/2017, 14 de diciembre de 2017 acogieron el recurso contra las otras dos normas citadas.

${ }^{38}$ SSTC 134/2017, de 16 de noviembre de 2017 y 145/2017, 14 de diciembre de 2017.

${ }^{39}$ Como indica López Insúa, con esta norma el derecho a la asistencia sanitaria se configura como un derecho de ciudadanía, de carácter universal y no solamente ligado a la nacionalidad y a la residencia. En
} 
Por lo que se refiere a las Observaciones finales del Sexto informe periódico de España, de 29 de marzo de 2018, de nuevo, se le reiteran las señaladas en el anterior, ante la pasividad y/o resistencia a su cumplimiento, insistiendo o añadiendo, entre otras, la aplicabilidad de "todos los derechos consagrados en el Pacto en todos los niveles del sistema judicial, inclusive mediante el recurso de amparo”, la realización de capacitaciones, especialmente entre jueces, abogados, etc., sobre la aplicabilidad del Pacto y la posibilidad de invocar los derechos ante los tribunales mediante un "mecanismo nacional eficaz para la aplicación y seguimiento de las recomendaciones y dictámenes del Comité”.

Me permito acentuar dos aspectos. Por un lado, el reenvío que realiza a la Declaración sobre Deuda pública, medidas de austeridad y Pacto Internacional de Derechos Económicos, Sociales y Culturales de 22 de julio de 2016, emitida con ocasión de los alegatos de los Estados de los incumplimientos por haber adoptado programas de consolidación fiscal, en particular programas de ajuste estructural o de austeridad, impuestos como condición para obtener préstamos. En este sentido, el CEDSC persevera en la inviabilidad de ignorar sus obligaciones de derechos humanos cuando toman decisiones en calidad de miembros de instituciones financieras internacionales o de otras organizaciones internacionales. Con ello, la delegación de facultades al FMI o a otros organismos o el ejercicio del derecho a votar en los mismos obviando los derechos humanos mostrará la infracción de sus obligaciones.

En suma, los Estados no se están exentos del cumplimiento del PIDESC, ni de su responsabilidad “(...) ni siquiera cuando, en su calidad de Estados miembros de una organización internacional, actuasen de plena conformidad con las reglas de la organización”.

Y finalmente, por otro lado, de nuevo le recordó que mientras siguiera vigente la exclusión sanitaria aludida no se están observando los arts. 2 y 12 del Pacto.

\subsubsection{El Protocolo de comunicaciones individuales: las Comunicaciones núm. 2/2014 y $5 / 2015$.}

Con la finalidad de asegurar progresar en los objetivos del Pacto y la aplicación de sus disposiciones, el 10 de diciembre de 2008 la Asamblea General aprobó el Protocolo Facultativo del PIDESC. Aplicable únicamente a los Estados que los suscriban, entre los que se encuentra España al haberlo firmado el 24 de septiembre de 2009 y ratificado el 9 de julio de 2010 (BOE de 25 de febrero de 2013), entró en vigor el 5 de mayo de 2013, tres meses después de producida la décima ratificación.

Como su denominación indica, se atribuye al CDESC competencia respecto de comunicaciones “(...) presentadas por personas o grupos de personas o grupos de personas que se hallen bajo la jurisdicción de un Estado Parte y que aleguen ser víctimas

"La recuperación de la universalidad de la asistencia sanitaria tras el Real Decreto-ley 7/2018, de 27 de julio”, Lex Social, Revista de Derechos sociales, 2019, 9-1 (en prensa), pp. 1 a 41. 
de una violación por ese Estado Parte de cualquiera de los derechos económicos, sociales y culturales enunciados en el Pacto” (art. 2). No es la única instaurada pues se añade también un procedimiento de investigación (art. 11 y ss.) y de comunicaciones interestatales ${ }^{40}$.

Para su admisibilidad, es preciso que la inste la víctima directa de la violación, se hayan agotado todos los recursos disponibles en la jurisdicción interna, no haya transcurrido más de un año de éste, salvo en los casos en que el autor pueda demostrar que no fue posible presentarla en ese plazo, se refiera a hechos sucedidos después de la fecha de entrada en vigor del Protocolo, aborde una cuestión que no haya sido examinada por el Comité o esté siendo examinada con arreglo a otro procedimiento de examen o arreglo internacional, no sea incompatible con las disposiciones del PIDESC, no sea manifiestamente infundada o no esté suficientemente fundamentada o se base exclusivamente en informes difundidos por los medios de comunicación, no constituya un abuso del derecho a presentar una comunicación, o, finalmente, no sea anónima o no se haya presentado por escrito (art. 2) ${ }^{41}$.

Tras su examen, el Comité del PIDESC se pronunciará sobre el fondo emitiendo una comunicación. Transcurridos cinco años, nuestro país es, además del primero a nivel europeo que lo ratificó, del que más denuncias se han presentado y el que más condenas ha recibido por el momento, como se muestra en la tabla siguiente:

\footnotetext{
${ }^{40}$ Véase un examen de las mismas en QUEL LÓPEZ. F.J., "Un paso esencial hacia la eficacia internacional de los derechos económicos, sociales y culturales. Luces y sombras del Protocolo Facultativo de Derechos Económicos, Sociales y Culturales”, en AA.VV., (Coord. TORRES BERNÁRDEZ, S., FERNÁNDEZ ROZAS, J.C., FERNÁNDEZ DE CASADEVANTE ROMANÍ, C., QUEL LÓPEZ J. Y LÓPEZ MARTÍN, A.G.), El Derecho Internacional en el mundo multipolar del siglo XXI. Obra homenaje al profesor Luis Ignacio Sánchez Rodríguez, Madrid, 2013, Iprolex, pp. 846 a 857.

${ }^{41}$ Indica VILLÁN DURÁN que otros Comités acogen los conceptos de "víctima indirecta" (un familiar de la víctima) o "potencial" (cualquier persona que pueda probar que se le puede aplicar de manera inminente una ley que haya sido declarada contraria al PIDESC" y, con ello, la posibilidad de que se pueda predicar también de este Protocolo. En "Protocolo Facultativo del Pacto Internacional de Derechos Económicos, sociales y culturales”, en Revista española de desarrollo y cooperación, 2009, n 13, p. 45. Véase también un estudio completo en DE SCHUTTER, O., "Le Protocole facultatif au pacte international relatif aux droits économiques, sociaux et culturels », Revue Belge de Droit International, 2006, nº 7, pp. 7 a 56.
} 


\section{Reclamaciones Comité PIDESC/Protocolo 2008}

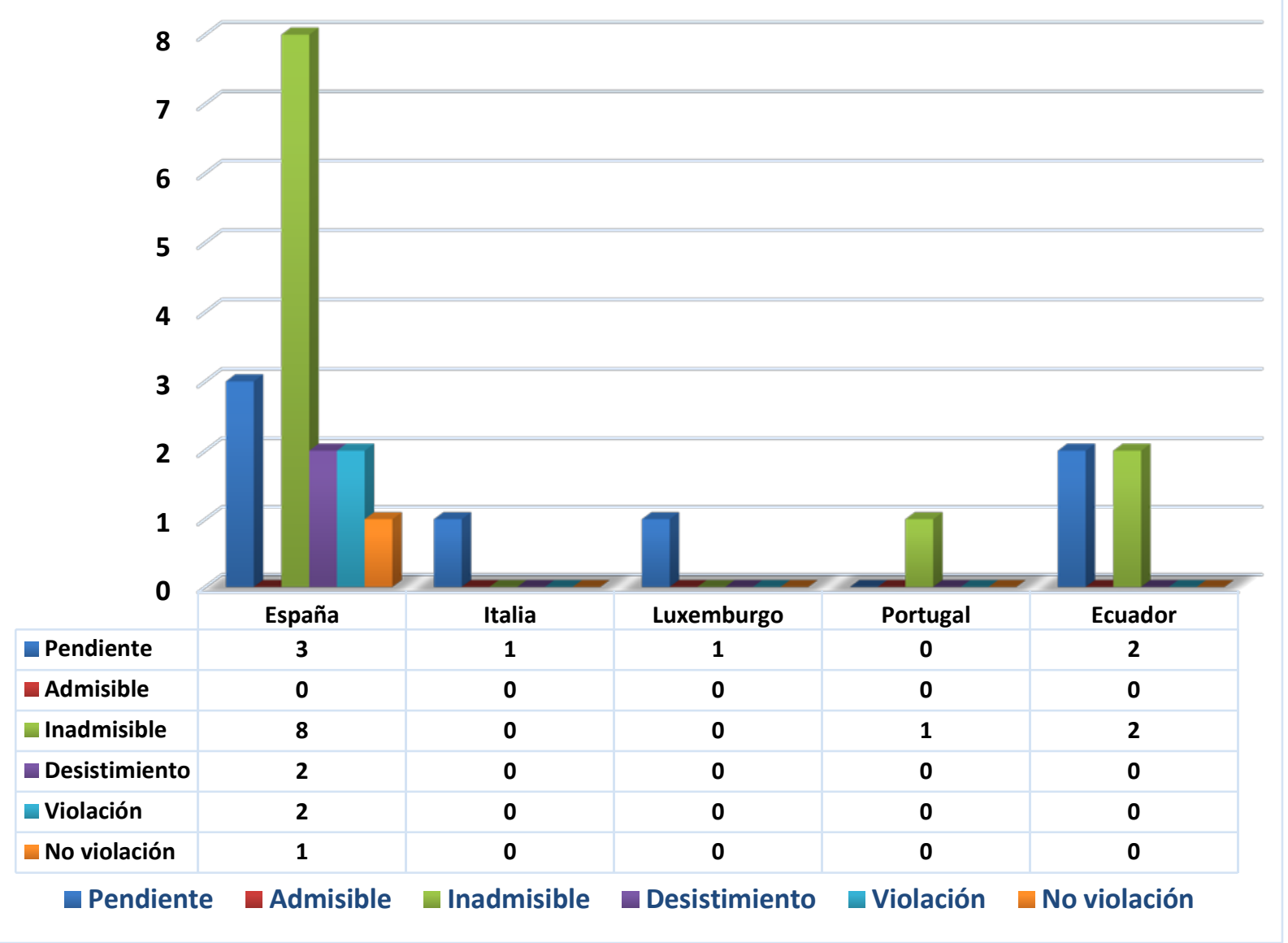

Tabla n 4 Elaboración propia Fuente: https://www.ohchr.org/Documents/HRBodies/CESCR/StatisticalSurvey.xls, última actualización disponible en web enero $2018^{42}$

Dos en concreto hay publicadas ${ }^{43}$, las Comunicaciones $n^{0}$ 2/2014 y 5/2015. En ambas se reconoció la violación del art. 11.1 del PIDESC, en combinación con el art. 2.1, en cuanto al derecho a una vivienda adecuada.

En el primer supuesto, se condena al Estado por no tomar las medidas razonables para notificar adecuadamente a la demandante una ejecución hipotecaria presentada por la entidad acreedora, con el fin de asegurarse que estuviera de hecho informada sobre el inicio del procedimiento. Con ello, el órgano judicial le impidió la posibilidad de defender adecuadamente su derecho a la vivienda ante un tribunal. La condena al Estado es la de

\footnotetext{
${ }^{42}$ La falta de actualización de ese apartado permite, no obstante, completarlos con los que se muestran en la Table of pending cases otro en la misma página web (https://www.ohchr.org/EN/HRBodies/CESCR/Pages/PendingCases.aspx), en el que se indica que hay presentadas contra nuestro país también desde la Comunicación $n^{\circ} 23$ hasta la $n^{\circ}$ 67, excepto la $n^{\circ} 61$ que va dirigida contra Bélgica.

43 No se consideró que había vulneración en la Comunicación $n^{\circ} 1 / 2013$. Se han inadmitido las $n^{\circ} 4,6,8$, 11, 12, 13, 17, 18 y 19. Respecto de las $\mathrm{n}^{\mathrm{o}} 15$ y 16 fue aceptado el desistimiento solicitado por los reclamantes.
} 
obligarle a proporcionar una reparación efectiva consistente, en particular, en asegurar que la subasta de la vivienda no se ejecute sin que ella cuente con la debida protección procesal y un proceso con las debidas garantías, conforme a las disposiciones del PIDESC y tomando en cuenta las observaciones generales del CDESC $\mathrm{n}^{0} 4$ y 7 , así como a reembolsar los costes legales incurridos en la tramitación de la comunicación.

Y, en cuanto al segundo, la violación se origina en el desalojo de los reclamantes (una familia con hijos menores), sin que les fuera garantizada una vivienda alternativa. La pareja, tras dejar de percibir el subsidio de desempleo, no pudo pagar la renta mensual de alquiler. Si bien la orden judicial de desahucio era legal, se condenó porque las autoridades no habían tomado todas las medidas necesarias para proporcionar a la familia una vivienda alternativa, imponiendo al Estado a que les proporcione una vivienda adecuada, evalúe la situación actual de los mismos y, en consulta genuina y efectiva, les otorgue una vivienda pública u otra medida que les permita vivir, les proporcione una compensación económica por las violaciones sufridas y reembolse los costes legales en que razonablemente hubieran incurrido en la tramitación de la comunicación ${ }^{44}$.

Los miembros del CDESC, subrayaron en este sentido, y ante la situación de crisis, que "todas las personas, incluidas aquellas que viven en régimen de arriendo, tienen el derecho a una vivienda”, debiendo los Estados, por tanto, garantizar que los desahucios no den lugar a situaciones en las que los afectados se queden sin un techo. Se insiste en la obligación, hasta el máximo de sus recursos disponibles, de proveer una vivienda alternativa a las personas objeto de desahucio que se encuentren en una situación de penuria y, en caso de no ser posible, “demostrar que, a pesar de que tomó todas las medidas necesarias, no le fue posible otorgar a la persona desahuciada una vivienda alternativa."

En resumen, en las últimas valoraciones efectuadas al Estado español, por vía del procedimiento de informes o de comunicaciones individuales, se le ha comunicado que incumple el Tratado internacional y, con ello, se están violando derechos humanos, que debe suprimir o corregir con base en el carácter vinculante que reviste y, con ello demostrar la realidad del Estado Social y Democrático de Derecho.

\subsection{El Consejo de Europa: la Carta Social Europea de 1961 y sus Protocolos.}

El estudio de los derechos sociales a nivel europeo debe incluir la normativa, por un lado, de la Unión Europea y, por otro lado, la del Consejo de Europa.

Sobradamente conocida la primera, es la segunda sobre la que hay que incidir con frecuencia $\mathrm{y}$, principalmente, en uno de sus tratados, la CSE, adoptada como complemento del Convenio Europeo para la Protección de los Derechos Humanos y de

\footnotetext{
${ }^{44}$ Un estudio más amplio en BELOVA, E., "Chronique des constatations du Comité des droits économiques, sociaux et culturels, année 2017 : quelques précisions sur la compétence ratione temporis et sur le droit au logement », La Revue des droits de l'homme, Actualités Droits-Libertés, consultado el 20 de abril de http://journals.openedition.org/revdh/3780, pp. 1 a 6
} 
las Libertades Fundamentales, que, si bien es el más importante en cuanto a la protección y garantía de los derechos humanos, son considerables las carencias respecto a los derechos sociales. Tan sólo se puede considerar que hay dos preceptos ad hoc, los arts. 4, que contiene la prohibición de la esclavitud y del trabajo forzado, y 11, sobre la libertad de reunión y de asociación, si bien, en ocasiones, se intenta una interpretación extensiva de otros preceptos para fundamentar demandas de ese ámbito. Claramente se precisaba de un texto adicional que los ampliara e integrara ${ }^{45}$, más si atiende a la jurisprudencia del Tribunal Europeo de Derechos Humanos, poco proclive a su apreciación cuando se le ha sometido alguna controversia pues, en la mayoría de supuestos que se le han sometido demandas sobre limitaciones de derechos sociales fundamentada en medidas de austeridad, las ha declarado "manifiestamente mal fundadas" e inadmisibles ${ }^{46}$.

Por ello, este apartado se dedica a examinar el Tratado más importante en materia de derechos sociales, que, en la actualidad, se ha erigido en "bastión" de defensa de los derechos sociales ${ }^{47}$, y, en consecuencia, del Estado social, exigiendo constantemente en la mayoría de reivindicaciones ciudadanas su cumplimiento.

Para situar al lector, la CSE se adoptó en Turín el 18 de octubre de 1961 para, según su Preámbulo, garantizar el goce de los derechos sociales sin discriminación por motivos de raza, color, sexo, religión, opinión política, proveniencia nacional u origen social, mejorar el nivel de vida y promover el bienestar de todas las categorías de la población, rurales o urbanas, por medio de instituciones y actividades apropiadas en los países que forman parte del Consejo de Europa.

La aprobación separada respecto del CEDH, así como el establecimiento de un procedimiento de vigilancia de su cumplimiento diferente, se justifica en el temor de conseguir un consenso por parte de los Estados “(...) sobre qué derechos se debían

\footnotetext{
${ }^{45}$ Explica AKANDJI-KOMBE que la estrecha relación es patente si se estudian los trabajos preparatorios de la CSE, puesto que el dictamen emitido por la Asamblea Parlamentaria del Consejo de Europa de septiembre de 1953 resaltaba que «(...) debería constituir en el ámbito social un homólogo del CEDH (...)», y el Comité de Ministros, en el mensaje especial que publicó en mayo de 1954, la caracterizó como «(...) el pariente del CEDH en el ámbito social». En «Carta Social Europea y Convenio Europeo de Derechos Humanos: perspectivas para la próxima década», Revista de Derecho Político, 2006, n. ${ }^{\circ}$ 67, pp. 387 y 388. Ese parentesco ha llevado a que se calificara, en un principio, a la CSE como la «hermana pobre» del CEDH, percepción que se ha superar habiendo contribuido a ello «(...) la fuerza progresivamente ganada por el principio de indivisibilidad de los derechos humanos». JIMENA QUESADA, L., «Retos pendientes del Estado Social Español: en especial, la ratificación de la Carta Social Europea revisada de 1996», Nuevas Políticas Públicas: Anuario multidisciplinar para la modernización de las Administraciones Públicas, 2006, n. ${ }^{\circ}$ 2, p. 42.

${ }^{46}$ Véase en este sentido, entre otras, las decisiones del TEDH de 7 de mayo de 2013, Ioanna Koufaki y Confederación de sindicatos de funcionarios públicos (ADEDY) contra Grecia, 8 de octubre de 2013, Conceição Mateus y Santos Januário y 1 de septiembre de 2015, Da Silva Carvalho Rico ambas contra Portugal, 15 de octubre de 2013, Savickas y otros y 4 de julio de 2017, Mockiene contra Lituania, 7 de diciembre de 2017, P. Plaisier B.V. contra los Países Bajos o la última el 19 de julio de 2018, Aielli y otros y Arboit y otros contra Italia.

47 JIMENA QUESADA, L., "El último bastión en defensa de los derechos sociales: La Carta Social Europea”. Revista Jurídica Universidad Autónoma de Madrid, 2014, n ${ }^{\circ} 29$. https://revistas.uam.es/revistajuridica/article/view/5607, pp. 1 a 19, último acceso 1/2/2019.
} 
garantizar, su alcance y el mecanismo de control” ${ }^{48}$, pues, si bien su adopción evidencia un progreso social, concretado, en el reconocimiento y mejora de los derechos sociales, la CSE se observa como una "(...) fuente de gastos adicionales que (...) han de soportar el Estado o los empresarios, [traduciéndose] esa carga, [exponiéndose] (...) al riesgo de ver debilitado su comercio internacional si no convence a los otros países para que realicen un progreso social similar, lo que en definitiva acarrea una concertación internacional en un mundo cada vez más globalizado (...)" 49 .

En la actualidad ese temor se ha de tener por superado dado que un total de 43 países han ratificado la CSE, originaria y/o revisada, entre los que se incluyen los 28 de la UE, debiendo garantizar un mínimo de preceptos, como luego se explicará, no existiendo, al menos teóricamente, diferencias muy notables. Ahora bien, se ha de informar que la pertenencia al Consejo de Europea se supedita a la ratificación del CEDH y no así a la CSE, existiendo cuatro países, Liechtenstein, Mónaco, San Marino y Suiza que, formando parte del mismo, no la han ratificado, dejando patente la posición secundaria que tiene incluso dentro del Consejo de Europa, que es aprovechada por la UE y los Estados que la incumplen, pese a que se ha reconocido la influencia directa en las normas comunitarias, citando en este sentido la Carta Europea de Derechos Fundamentales ${ }^{50}$.

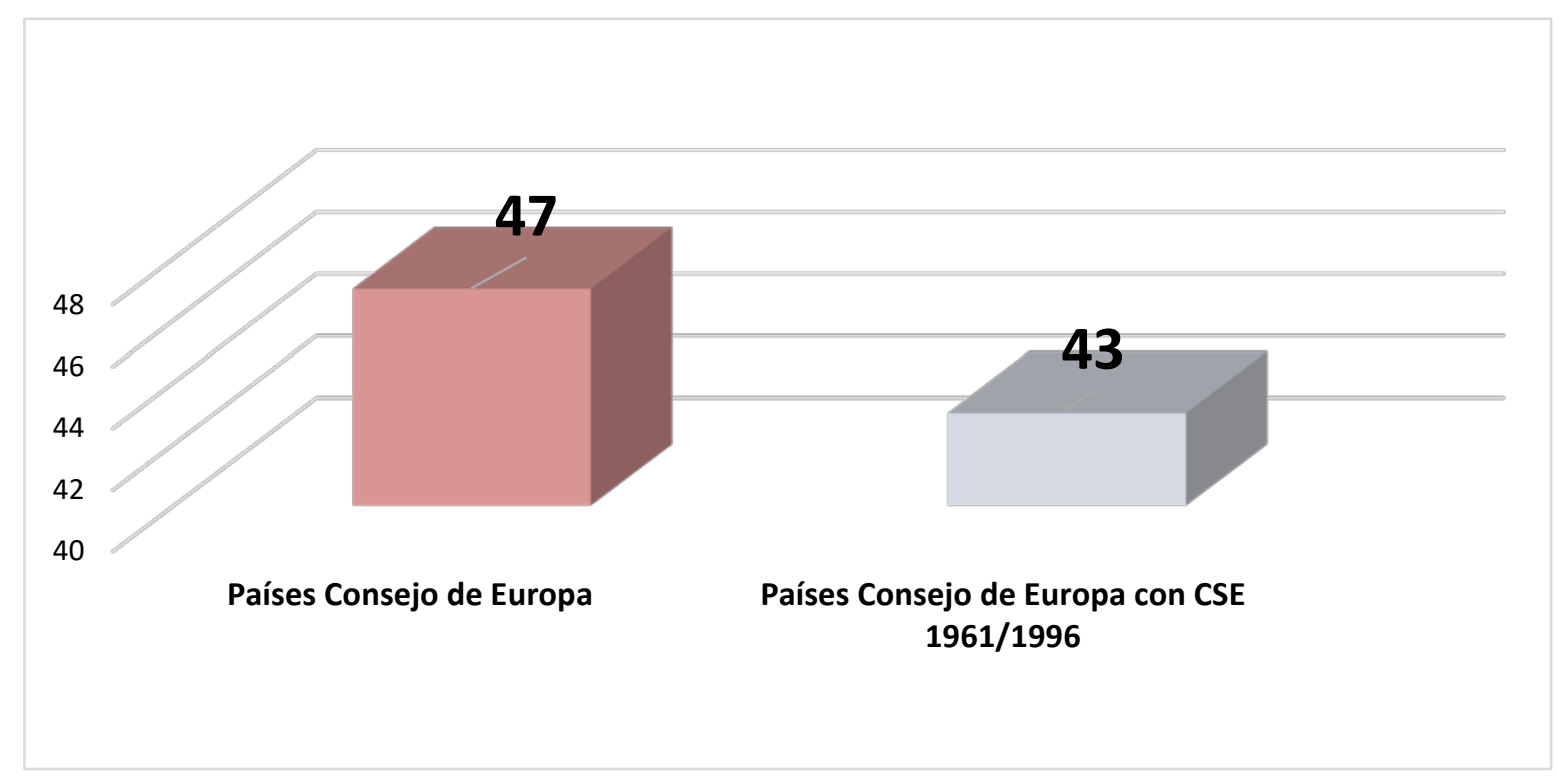

\footnotetext{
${ }^{48}$ PRIETO SUÁREZ, R..: "La Carta Social Europea y el Comité Europeo de Derechos Sociales (el sistema de informes y las reclamaciones colectivas)”. Revista Europea de Derechos Fundamentales, 2008, nº 11. Pág. 356.

49 JIMENA QUESADA, L.: La Jurisprudencia del Comité Europeo de Derechos Sociales. Valencia, 2007. Tirant lo Blanch. Pág. 19.

${ }^{50}$ Así se constata en las Explicaciones anejas a la Carta Europea de Derechos Fundamentales elaboradas bajo la responsabilidad del Prcesidium (Diciembre, 2000). Luxemburgo, 2001. Servicio de Publicaciones Oficiales de las Comunidades Europeas. En ellas “(...) queda claro que tanto la Carta Social de 1961 como, sobre todo, la Carta Social revisada de 1996, han impregnado la redacción de buena parte de las disposiciones de la Carta de la UE”. JIMENA QUESADA, L.: “La Carta Social Europa y la Unión Europea”. Revista Europea de Derechos Fundamentales, 2009, nº 13. Pág. 402.
} 
Tabla $n^{\circ} 5$ Elaboración propia Fuente https://www.coe.int/fr/web/european-social-charter/signatures-ratifications, última actualización 21/3/19

Estructura en cinco partes, la primera recoge los «objetivos» que asumen las Partes contratantes a la hora de elaborar su política y enumera 19 puntos. Literalmente dispone que "Las Partes reconocen como objetivo de su política, que habrá de seguirse por todos los medios adecuados, tanto de carácter nacional como internacional, el establecimiento de las condiciones en que puedan hacerse efectivos los derechos y principios siguientes (...)".

La Parte II establece, como «compromisos» de las Partes contratantes, a considerarse "vinculadas por las obligaciones establecidas en los artículos y párrafos siguientes (...)”, reiterando a continuación todos los puntos anteriores, completando su contenido con subapartados. Específicamente en ellos se contempla el compromiso de garantizar el efectivo derecho al trabajo (art. 1), unas condiciones de trabajo equitativas (art. 2), la seguridad e higiene en el trabajo (art. 3), una remuneración equitativa (art. 4), promover la libertad sindical de los trabajadores y empleadores (art. 5), la negociación colectiva (art. 6), la protección de niños y adolescentes (art. 7), la protección de las trabajadoras (art. 8), la orientación y formación profesional (arts. 9 y 10), la protección de la salud (art. 11), la seguridad social (art. 12), la asistencia social y médica (art. 13), los beneficios de los servicios sociales (art. 14), la formación profesional y readaptación profesional y social de las personas física o mentalmente disminuidas (art. 15), la protección social, jurídica y económica de la familia, las madres y niños (arts. 16 y 17), el ejercicio de una actividad lucrativa en el territorio (art. 18) y, finalmente, la protección y asistencia de los trabajadores migrantes y sus familias (art. 19).

En suma, dos partes diferenciadas en su ubicación en el texto y, lo más importante, en cuanto a su vinculación que, a mi juicio, se deduce fácilmente de las palabras que he entrecomillado en las que es incuestionable la diferente redacción y efectos, programáticos la primera, obligatorios y vinculantes los de la segunda.

Esto se confirma también con dos argumentos adicionales. Primero, con la Parte III de la CSE, que explica el peculiar sistema de ratificación, en el que es posible que no todos los Estados estén obligados por las mismas disposiciones. Estos se comprometen, por un lado, según la redacción del art. 20.1 a) y b) de la CSE, «(...) a considerar la Parte I (...) como una declaración de los objetivos que tratará de alcanzar por todos los medios adecuados (...) [y] a considerarse obligada por al menos cinco de los siete artículos siguientes de la Parte II (...)».

Y, por otro lado, los Estados han de suscribir además «(...) un número adicional de artículos o párrafos numerados de la Parte II de la Carta que elija dicha parte contratante, siempre que el número total de los artículos y de los párrafos numerados a los que quedará obligada no sea inferior a 10 artículos o a 45 párrafos numerados» (art. 20.1 c) de la CSE).

El segundo argumento se obtiene del Anexo a la CSE que es claro en relación con la Parte III, al disponer literalmente que "se entiende que la Carta contiene obligaciones jurídicas 
de carácter internacional cuya aplicación está sometida únicamente al control establecido en la Parte IV”.

España ratificó en su totalidad esta CSE originaria por Instrumento de 29 de abril de 1980 (BOE de 26 de junio de 1980) ${ }^{51}$, estando, en consecuencia, vinculada por las garantías y derechos reconocidos y las interpretaciones que realice el CEDS, que ha de calificarse como jurisprudencia.

La necesidad de adaptarse a la evolución y cambios de la realidad social, dio lugar a que, tras unos años, fuera ampliada y/o enmendada con la aprobación de tres Protocolos. El primero, de 5 de mayo de 1988 (Adicional), añadió cuatro derechos que mejoraron la protección de los trabajadores. Fue firmado por España el 5 de mayo de 1998 y ratificado en su totalidad el 24 de enero de 2000 (BOE de 25 de abril).

El segundo, de 21 de octubre de 1991 (Enmienda), modifica algunos artículos con objeto de mejorar “(...) la eficacia de la Carta y, en particular, el funcionamiento de su mecanismo de control”. Se trata de una norma que presenta la peculiaridad de que aún no ha entrado en vigor puesto que requiere “(...) que todas las Partes Contratantes de la Carta hayan expresado su consentimiento a quedar vinculadas (...)” (art. 7), estando en estos momentos ratificado sólo por 23 países. El Comité de Ministros en la 467 Reunión de 26 de diciembre de 1991 adoptó la Decisión de que en la práctica se aplicara, con la excepción del sistema de designación de los componentes del CEDS. Al igual que el anterior, fue firmado por España el 21 de octubre de 1991 y ratificado el 24 de enero de 2000 (BOE de 25 de abril),

Finalmente, el significativo tercer y último Protocolo, de 9 de noviembre de 1995, instauró un sistema de reclamaciones colectivas y avanzar en “(...) la aplicación efectiva de los derechos sociales garantizados”, reforzando “(...) la participación de los empresarios y trabajadores, así como de las organizaciones no gubernamentales”. España no ha firmado ni ratificado este Protocolo.

El escenario que se ha descrito precisaba que se ordenara y por ello se aprobó el 3 de mayo de 1996 la CSE revisada, que incluye un total de 31 derechos (19 de la versión originaria, 4 del primer protocolo de 1988 y 8 nuevos). Específicamente estos son el derecho a la protección en caso de despido (art. 24), el derecho de los trabajadores a la tutela de sus créditos en caso de insolvencia de su empleador (art. 25), el derecho a la dignidad en el trabajo (art. 26), el derecho de los trabajadores con responsabilidades familiares a la igualdad de oportunidades y de trato (art. 27), el derecho de los representantes de los trabajadores a protección en la empresa y facilidades que se les deberán conceder (art. 28), el derecho de información y consulta en los procedimientos

\footnotetext{
${ }^{51}$ Un estudio completo en GARCÍA GONZÁLEZ, G., "La recepción de la Carta Social Europea en el ordenamiento español: aspectos jurídicos, políticos e institucionales (1978-2018)”, Revista del Ministerio de Empleo y Seguridad Social, 2018, nº 137, pp. 43 a 78.
} 
de despido colectivo (art. 29), el derecho a protección contra la pobreza y la exclusión social (art. 30) y el derecho a la vivienda (art. 31).

España firmó la CSE revisada el 23 de octubre de 2000 pero está pendiente su ratificación, siendo muy criticable ya que sitúa a nuestro país fuera de la mayoría en cuanto a los derechos sociales. Recientemente tuvo muy favorable acogida y difusión el Acuerdo del Consejo de Ministros de 1 de febrero de 2019 por el que se disponía la remisión a las Cortes Generales de la Carta Social Europea revisada y se autoriza la manifestación del consentimiento de España para obligarse por la misma. Lamentablemente el trámite se ha paralizado al convocarse nuevas elecciones. Habrá que esperar a verificar si éste interés se confirma o si se sigue suspendiendo en este sentido tras la constitución del nuevo gobierno.

No está de más recordar que el Consejo de Estado dictaminó el 11 de mayo de 2000 (Expediente $\left.n^{0} 1740 / 2000\right)$, en relación con la misma, que, “(...) en principio no plantea problemas de aplicación en nuestro país, ya que concuerda con nuestro derecho interno, por lo que (...) no implicaría la necesidad de modificar nuestra legislación (...)”, estando “(...) ante un tratado internacional que incide sobre derechos y deberes fundamentales establecidos en el Título I de la Constitución (artículos 14, 35, 37, 40 y 50) y que recae sobre materias reguladas por Ley en el ordenamiento español (...), [estimándose] comprendido en los párrafos c) y e) del artículo 94.1 de la Constitución, con el consiguiente requerimiento de autorización de las Cortes Generales con carácter previo a su conclusión”.

\section{Países Consejo Europa según versión CSE}

Ratificación CSE 1996

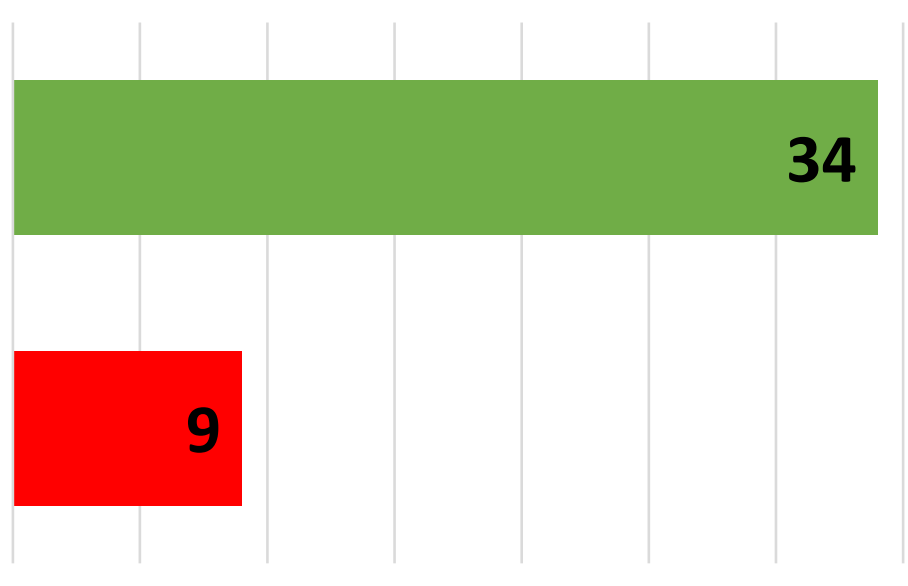

$\begin{array}{lllllllll}0 & 5 & 10 & 15 & 20 & 25 & 30 & 35 & 40\end{array}$

Tabla $n^{\circ} 6$ Elaboración propia Fuente https://www.coe.int/fr/web/european-social-charter/signatures-ratifications, última actualización 21/3/19.

Por lo que se refiere a los mecanismos de control, el propio Tratado los determina, específicamente dos. Por un lado, el sistema de informes, aplicable a todos los Estados 
que han ratificado la CSE, originaria y/o revisada, y, por otro lado, el procedimiento de reclamaciones colectivas, únicamente operativo para los Estados que han ratificado el protocolo de 1995 establecido ad hoc o se realice una declaración específica por el país, al suscribir la CSE, originaria y/ revisada, aceptando la supervisión de sus obligaciones derivadas de la misma según el procedimiento establecido en dicho Protocolo (art. D.2 parte IV).

Los dos sistemas son tramitados y resueltos por el Comité Europeo de Derechos Sociales, compuesto por quince miembros independientes elegidos por el Comité de Ministros del Consejo de Europa por un mandato de seis años (renovable una sola vez). Se configura como la instancia suprema de garantía de la CSE, equivalente al Tribunal Europeo de Derechos Humanos con respecto al Convenio Europeo de Derechos Humanos, asegurando la interpretación auténtica y, lógicamente, de carácter vinculante de la CSE, en forma de jurisprudencia.

\subsubsection{El Procedimiento de Informes y las Conclusiones emitidas a España}

Una vez se ha desarrollado la normativa ratificada por España con sus principales características, se efectuará de los mecanismos de control de su cumplimiento dedicando este apartado al procedimiento de informes. Se instauró junto con la aprobación de la CSE, de forma obligatoria a todos los Estados que la suscriben. Se encuentra regulado en la Parte IV de la CSE (arts. 25 a 29), y en su desarrollo, intervienen tres organismos, el CEDS, el Comité Gubernamental y el Comité de Ministros.

El primero es el máximo órgano encargado de la interpretación, defensa y control en cuanto a la normativa y práctica de los Estados, que, sin tener formalmente carácter jurisdiccional, emite conclusiones y decisiones de fondo de carácter vinculante. Está compuesto por quince expertos independientes e imparciales, de máxima integridad y competencia reconocida en cuestiones sociales internacionales, elegidos por el Comité de Ministros, para un mandato de seis años, renovable una vez (art. 25 CSE).

Las Partes contratantes le remiten cada año al CEDS un Informe en el que explican cómo están observando la CSE en su país al aprobar la normativa o ejecutar una práctica. El contenido no versa sobre la totalidad de la CSE sino sobre el grupo temático correspondiente a ese año, habiendo organizado cuatro, el Grupo 1 sobre empleo, formación e igualdad de oportunidades (arts. 1, 9, 10, 15, 18, 20, 24 y 25 de la CSE -art. 1 del Protocolo de 1988-), el Grupo 2 sobre salud, seguridad social y protección social (arts. 3, 11, 12, 13, 14, 23 y 30 de la CSE -art. 4 del Protocolo de 1988-), el Grupo 3 sobre derechos relacionados con el trabajo (arts. 2, 4, 5, 6, 21, 22, 26 y 28 de la CSE -arts. 2 y 3 del Protocolo de 1988) y el Grupo 4 sobre niños, familia y migrantes (arts. 7, 8, 16, 17, 19, 27 y 31)

Los Estados están obligados a enviar a las organizaciones sindicales y empresariales más representativas de ámbito nacional copia de estos informes, pudiendo éstas, a su vez, presentar observaciones a los mismos (art. 23), calificándose de muy importantes pues 
suministran información adicional que puede haber omitido el país, de forma interesada, al presentar el Informe.

Toda la documentación aportada pasa a ser examinada, durante el año siguiente, por el CEDS, que finalmente dicta unas Conclusiones en las que decide la conformidad o no del país a la CSE originaria o revisada y al Protocolo de 1988, imponiendo, en el segundo caso, a los Estados Parte la adopción de medidas de mejora o corrección.

En ese examen se ha de tener claro que, si bien se pueden valorar y analizar estudios, documentación o información que se facilite a otra organización internacional, a modo de ejemplo, la presentada o relacionada con la OIT o la ONU, la (in)existencia de (in)cumplimento o de resolución de condena/absolución no impide que, a juicio del CEDS, en la misma situación objeto de estudio, se pronuncie en sentido contrario, puesto que se trata de un marco regulador diferente.

Tras la publicación de las Conclusiones, se transmiten al Comité Gubernamental, órgano compuesto por un representante de los gobiernos de cada una de las Partes Contratantes, que supervisará el cumplimiento de las Conclusiones. Este trámite se desarrolla invitando, como máximo, “(...) a dos organizaciones internacionales de empleadores y a dos organizaciones internacionales de trabajadores, para que envíen observadores a título consultivo a sus reuniones (...)” y convoca “(...) para consulta a representantes de organizaciones internacionales no gubernamentales reconocidas como entidades consultivas por el Consejo de Europa y que tengan especial competencia en las materias reguladas (...)” por la CSE (art. 27.2).

Seguidamente, “(...) preparará las decisiones del Comité de Ministros (...)”, seleccionando de manera motivada “(...) sobre la base de consideraciones de política social, económica y de otra índole, aquellas situaciones que, a su juicio, deberían ser objeto de recomendaciones dirigidas a las Partes Contratantes interesadas (...)” presentando finalmente un informe (art. 27.3) $)^{52}$.

En último lugar interviene el Comité de Ministros, órgano decisorio del Consejo de Europa. Lo conforman ministros de Exteriores de todos los Estados miembros o sus representantes permanentes en Estrasburgo. Su función principal es la de vigilar, junto con la Asamblea Parlamentaria, que se apliquen los valores para los que se fundó el Consejo de Europa, supervisando el cumplimiento de los compromisos aceptados por los Estados miembros. Puede emitir, por una mayoría de dos tercios de los miembros, una Recomendación solicitando que modifique y adapte su normativa a los dictados del Convenio (art. 29). No debe confundirse la naturaleza jurídica de esta incursión, y así ha precisado en alguna ocasión el CEDS, de forma que “(...) la apreciación jurídica de la conformidad o no de la situación con la Carta corresponde únicamente al Comité Europeo

\footnotetext{
52 BRILLAT, R.: "La actividad pre-convencional y para-convencional del Consejo de Europa en el ámbito de los derechos sociales”. En AA.VV. (Coord. JIMENA QUESADA, L.): Escritos sobre derecho europeo de los derechos sociales. Valencia, 2004. Tirant lo Blanch. Pág. 21.
} 
de Derechos Sociales (...); el Comité de Ministros no ostenta la facultad de poner en entredicho la apreciación jurídica del Comité (...), sino solamente la de emitir o no una Recomendación al respecto dirigida al Estado afectado"53.

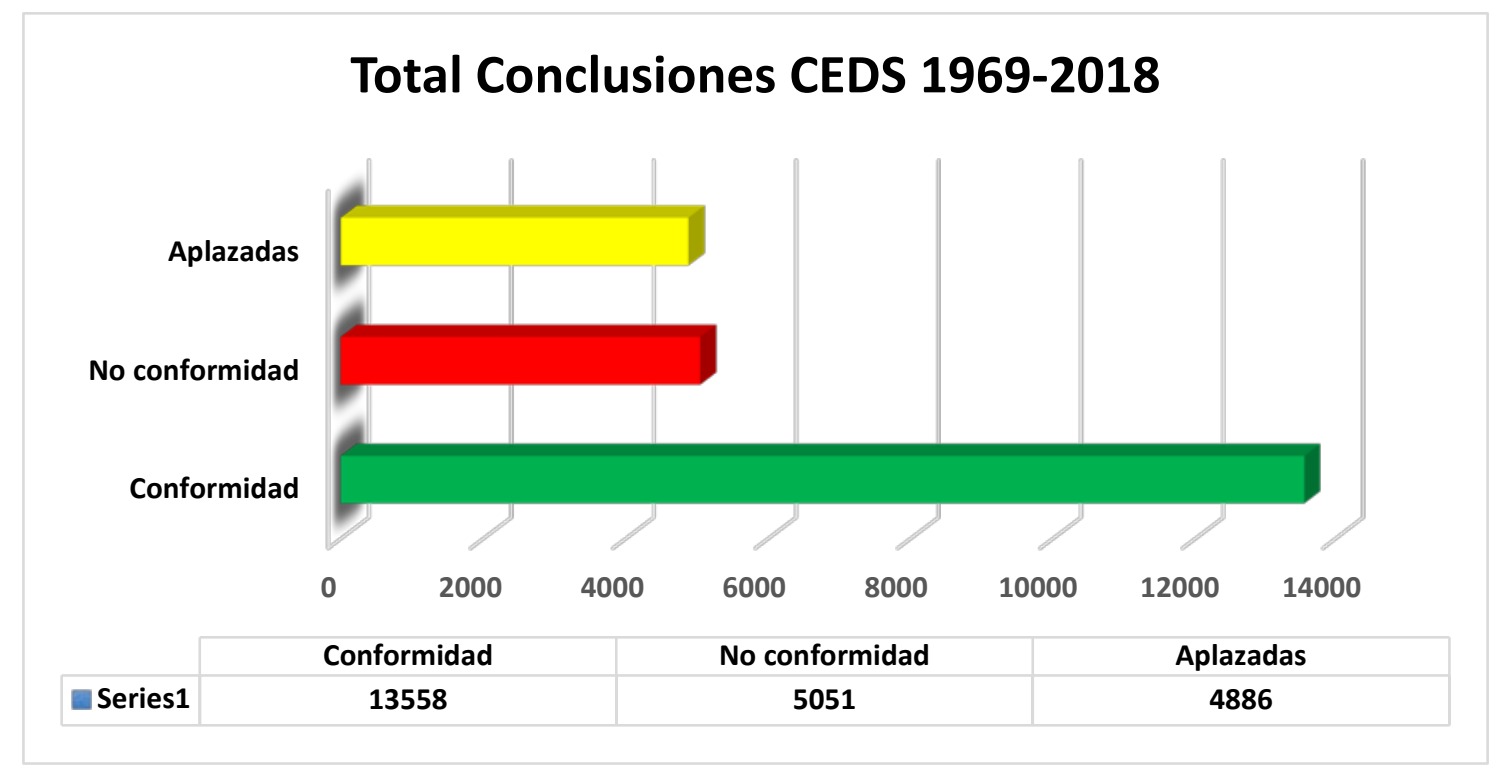

Tabla nº 7 Elaboración propia Fuente http://hudoc.esc.coe.int/eng/\# , última actualización 25/3/19.

El 25 de marzo de 2019 se han publicado las Conclusiones XXI-3 (2018) pertenecientes al Grupo 3. La valoración general emitida por el CEDS es que, si bien los países han evolucionado positivamente en algunos ámbitos relativos a los derechos de los trabajadores, tienen dificultades para observar todos los requerimientos de la CSE. Esta afirmación la fundamenta con los datos que se suministran tras el examen elaborado a 35 países de los 43 que han suscrito el Tratado, en el que de 580 conclusiones emitidas, 276 son de conformidad, 206 de no conformidad y 98 son aplazadas ante la falta de información. En suma, y teniendo en cuenta que, en el supuesto de que las últimas sean ignoradas o no corregidas, pasan a ser de no conformidad, el estado de cumplimiento de la Constitución Social de Europa es más que cuestionable.

La mayoría de ellas se originan en la carencia de un período razonable de preaviso en caso de despido, el derecho de los trabajadores a llevar a cabo acciones colectivas, incluido el derecho a la huelga y las reglas reguladoras del alcance en los supuestos

\footnotetext{
53 Reclamación no 16/2003 (Confederación francesa de directivos-Confederación general de ejecutivos contra Francia, decisión de fondo de 12 de octubre de 2004). Se añade que “(...) el Comité de Ministros, cuando decida hacer uso de esta facultad, puede ciertamente tener en cuenta consideraciones de orden económico y social en la motivación de la eventual recomendación, pero no puede poner en tela de juicio la apreciación jurídica”.
} 
retenciones salariales, seguidas de la fijación de salarios por debajo de un umbral adecuado (60\% del salario medio neto).

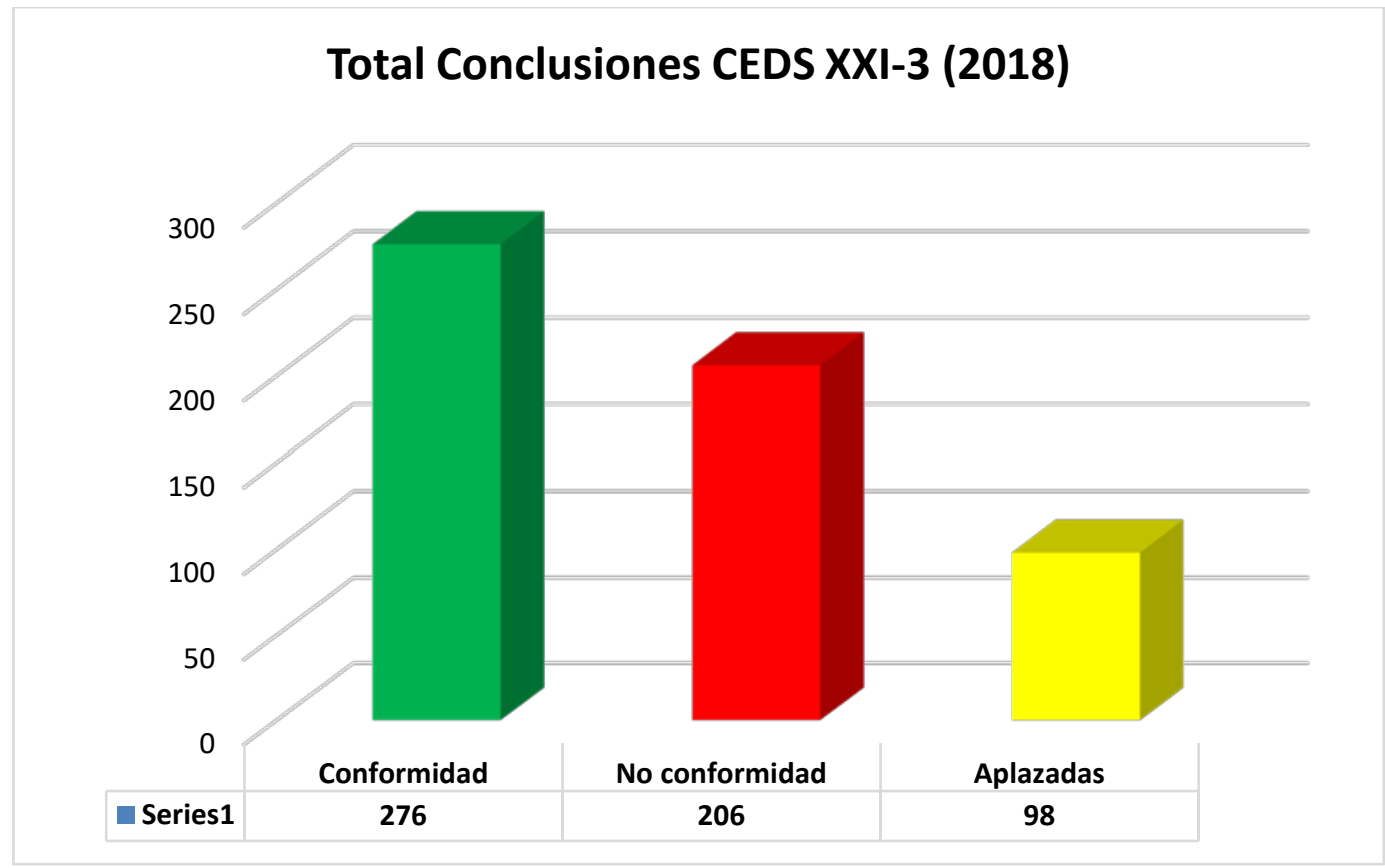

Tabla nº 8 Elaboración propia Fuente http://hudoc.esc.coe.int/eng/\# , última actualización 25/3/19.

Este resultado, unido al último realizado de los otros tres grupos temáticos muestra que, en cuanto a la totalidad del articulado, la situación es de significativos incumplimientos, en los que en algún período están muy próximas a las que se ha determinado su respeto. Si se adicionan a los primeros las diferidas, habitualmente no contempladas por los responsables, con la excepción del Grupo 4, se puede aseverar incluso que es mayor el número de infracciones. 


\section{Conclusiones CEDS totalidad preceptos 2015-2018}

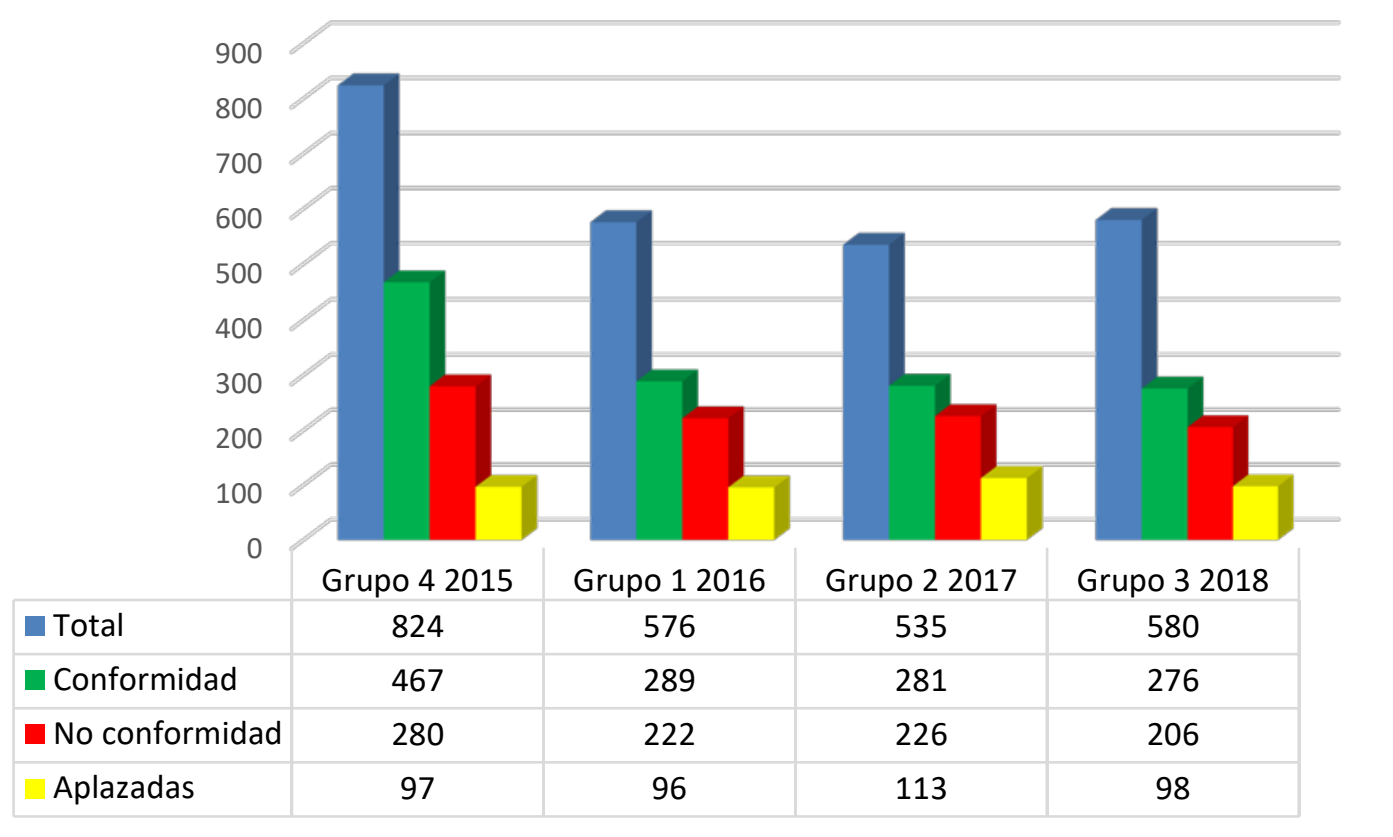

Tabla nº 9 Elaboración propia Fuente http://hudoc.esc.coe.int/eng/\# , última actualización 25/3/19.

En cuanto a España, los datos reflejan la apreciación general en cuanto a la existencia de infracciones de los compromisos asumidos guardando cierto paralelismo con los que lleva incurriendo desde hace años. 


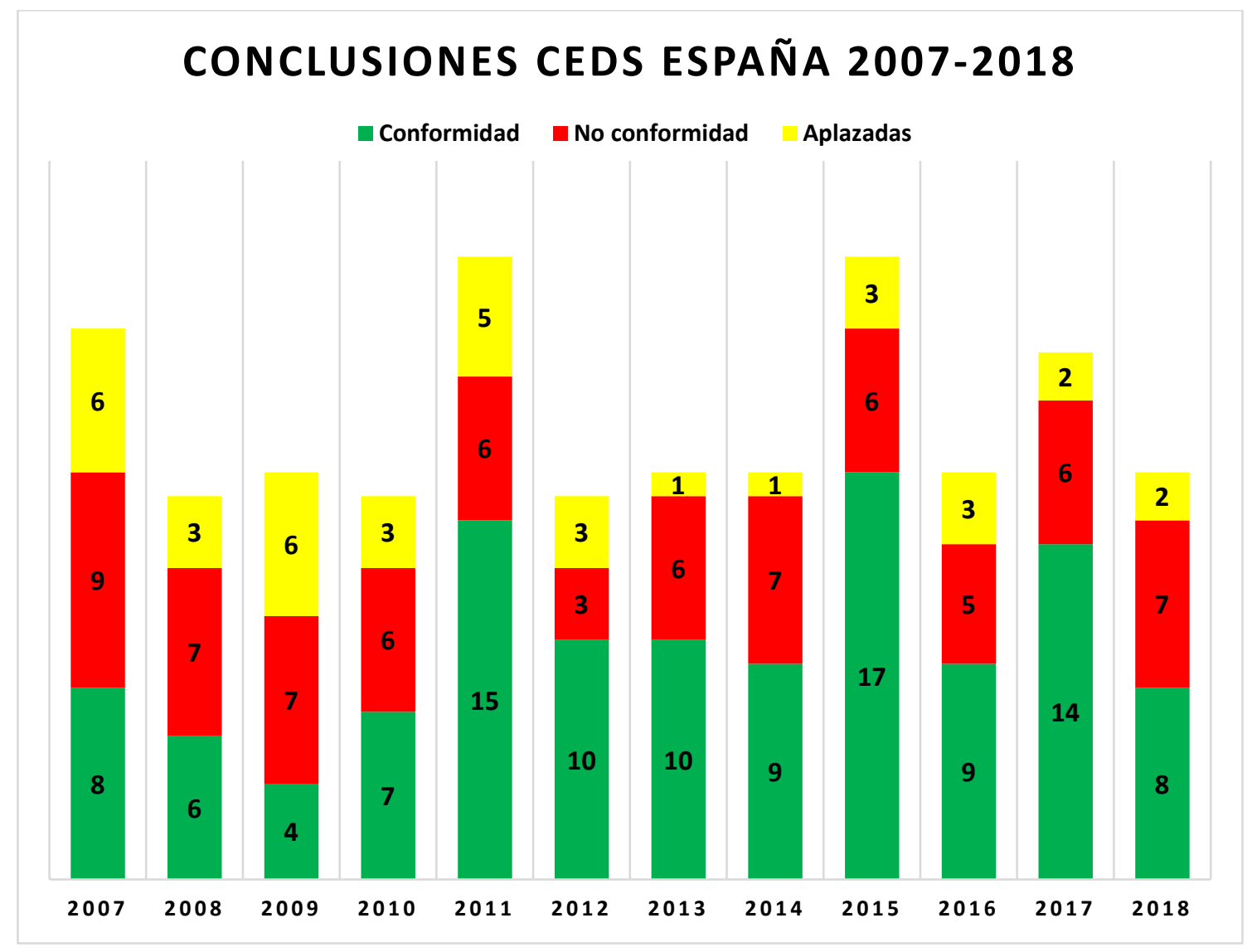

Tabla nº 10 Elaboración propia Fuente http://hudoc.esc.coe.int/eng/\# , última actualización 25/3/19.

\begin{tabular}{|l|r|r|r|}
\hline Grupo 1 & 2016 & 2012 & 2008 \\
\hline Grupo 2 & 2017 & 2013 & 2009 \\
\hline Grupo 3 & $\mathbf{2 0 1 8}$ & $\mathbf{2 0 1 4}$ & $\mathbf{2 0 1 0}$ \\
\hline Grupo 4 & 2015 & 2011 & 2007 \\
\hline
\end{tabular}

En el examen particular del último control ejecutado en 2018 se han comunicado 17 conclusiones en total, 8 supuestos son de conformidad, 7 de no conformidad y 2 han sido pospuestas -el período de referencia en cuanto a normativa y prácticas es desde el 1 de enero de 2013 al 31 de diciembre de 2016-.

Prácticamente no hay variaciones importantes respecto de las de efectuadas en el período 2010 y 2014, en los que se trataron los mismos preceptos, puesto que el Gobierno no ha corregido las anomalías detectadas y, por tanto, las condenas se reiteran.

En éste específicamente se incumplen, en primer lugar, dos apartados del art. 2, que regula el derecho a unas condiciones de trabajo equitativas. Por lo que se refiere al primero ante la legitimidad del art. 34.2 del ET de la distribución irregular de la jornada, se produce la 
no conformidad debido a que "la duración máxima del trabajo puede ser superior a las 60 horas semanales en el marco de fórmulas flexibles de organización del tiempo de trabajo y para algunas categorías de trabajadores”, en coherencia con la jurisprudencia del CEDS que ha resuelto sobre esta materia desde hace tiempo, entre otras, en la decisión de fondo de 16 de noviembre de 2001, Confédération française de l'Encadrement CFE-CGC c. France reclamación colectiva $n^{\circ}$ 9/2000.

Relacionado con este precepto, el CEDS volvió a requerir, sin éxito, información adicional sobre el número de supuestos en lo que los empresarios ha distribuido, en defecto de pacto, ese $10 \%$ de la jornada y a tener en cuenta, a efectos de las siguientes conclusiones, que se ha solicitado también sobre la caracterización de los períodos de guardia localizada y su asimilación a tiempo de trabajo o de descanso.

En cuanto al otro apartado que se incumple del precepto aludido, el tercero, se determina la no conformidad puesto que el informe presentado por el Gobierno relata que se garantiza que todos los trabajadores, como mínimo, tienen derecho a disfrutar de manera ininterrumpida de cinco días de vacaciones frente a la exigencia de que alcance a dos semanas.

En lo que atañe al art. 4, que garantiza el derecho a una remuneración equitativa, las violaciones son también conocidas. Del párrafo primero, de nuevo, el SMI del período analizado, atendiendo al parámetro que utiliza el CEDS con los datos del EUROSTAT, no garantiza "un nivel de vida decente", ni tampoco el de determinada categoría de trabajadores de la función pública (agentes contractuales).

Con referencia al apartado segundo del art. 4 de la CSE, se reproduce la condena anterior respecto a la remuneración de las horas extraordinarias, ante la ausencia de prueba fehaciente de su mayor remuneración o descanso compensatorio.

Los incumplimientos del art. 4.4 de la CSE se producen al no considerar razonable el plazo de preaviso de 6 meses para los despidos objetivos respecto de trabajadores con más seis meses de antigüedad así como su inexistencia de los que están en período de prueba del contrato de apoyo a emprendedores (en la actualidad derogado) o en los supuestos de finalización por muerte o incapacidad del empresario.

Para terminar, el art. 6 es el que determina la vulneración, por un lado, del apartado 2 en cuanto a la normativa que legitima la decisión del empresario de inaplicar las condiciones acordadas en un convenio colectivo (art. 41 del ET) y, por otro lado, del apartado 4, al concluir que la situación no es conforme al “(...) autorizar al Gobierno a que imponga el recurso al arbitraje para poner fin a una huelga en casos que van más allá de los límites previstos por el artículo 31 de la CSE”.

Brevemente apuntaré que las dos conclusiones que se retrasan, se circunscriben, por una parte, en el art. 2.4 de la CSE, demandando información que demuestre que los 
trabajadores que desempeñan actividades peligrosas o insalubres tienen reconocida una reducción de jornada, días de vacaciones pagadas suplementarios, medidas preventivas adicionales así como actuaciones de la inspección de trabajo que constaten la supervisión de estos aspectos, como exige el precepto.

Y, por otra parte, en cuanto al art. 6.3 de la CSE y el arbitraje obligatorio de la Comisión Consultiva Nacional de Convenios colectivos, solicitando que se concrete si su intervención es para conflictos jurídicos o de intereses así como la intervención de los sindicatos durante la sustanciación del procedimiento.

Como se puede constatar, de nuevo, violaciones de derechos sociales a España, que afectan directamente a los ciudadanos y que el Estado no corrige, obviando, además, la exigencia que el CEDS introdujo de forma general en las Conclusiones XIX-2 (2009) del CEDS sobre La aplicación de la Carta Social Europea en el contexto de la crisis económica global en la que les recordó a todos los países que "Las Partes, al suscribir la Carta Social Europea (...) han aceptado perseguir por todos los medios útiles la realización de condiciones aptas para asegurar el ejercicio efectivo de un cierto número de derechos, especialmente el derecho a la salud, el derecho a la seguridad social, el derecho a la asistencia social y médica y el derecho a los servicios sociales”, así como que "la crisis económica no debe traducirse en una reducción de la protección de los derechos reconocidos por la Carta (...); los Gobiernos deben adoptar todas las medidas necesarias para conseguir que esos derechos sean efectivamente garantizados en el momento en que la necesidad de protección se hace sentir más (...)”.

\subsubsection{El Protocolo de reclamaciones colectivas: la invocabilidad en las instancias judiciales españolas de las decisiones de fondo contra Grecia y Francia}

La aprobación de este sistema de control se realizó con la finalidad, como señala el Preámbulo del Protocolo que lo regula, de “(...) mejorar la aplicación efectiva de los derechos sociales garantizados por la Carta”, considerando que ese objetivo puede conseguirse, en particular "(...) mediante el establecimiento de un procedimiento de reclamaciones colectivas que, entre otros aspectos, reforzaría la participación de los empresarios y trabajadores, así como de las organizaciones no gubernamentales”.

A diferencia del anterior, este sistema es facultativo, siendo preciso que se ratifique el instrumento que lo regula o se realice una declaración específica por el país, al suscribir la CSE, aceptando la supervisión de sus obligaciones derivadas según el procedimiento establecido en dicho Protocolo (declaración prevista en el art. D.2 de la parte IV de la propia Carta revisada). En otras palabras, la ratificación de la Carta revisada habilita explícitamente para aceptar simultáneamente ese sistema de reclamaciones. De hecho, esa vía ha sido utilizada por dos de los quince países que ya han aceptado el procedimiento de reclamaciones colectivas, en concreto: de un lado, Eslovenia, que ratificó la Carta revisada el 7 de mayo de 1999 aceptando al tiempo el sistema de reclamaciones colectivas 
con base en el citado art. D.2; y, de otro lado, Bulgaria, que hizo lo mismo el 7 de junio de $2000^{54}$.

Por ello, hay 34 países que han ratificado la CSE y el Protocolo de reclamaciones colectivas sólo se puede utilizar en 15 y de estos, dos han suscrito el Protocolo sin tener aún la versión revisada (Croacia y República Checa ${ }^{55}$ ).

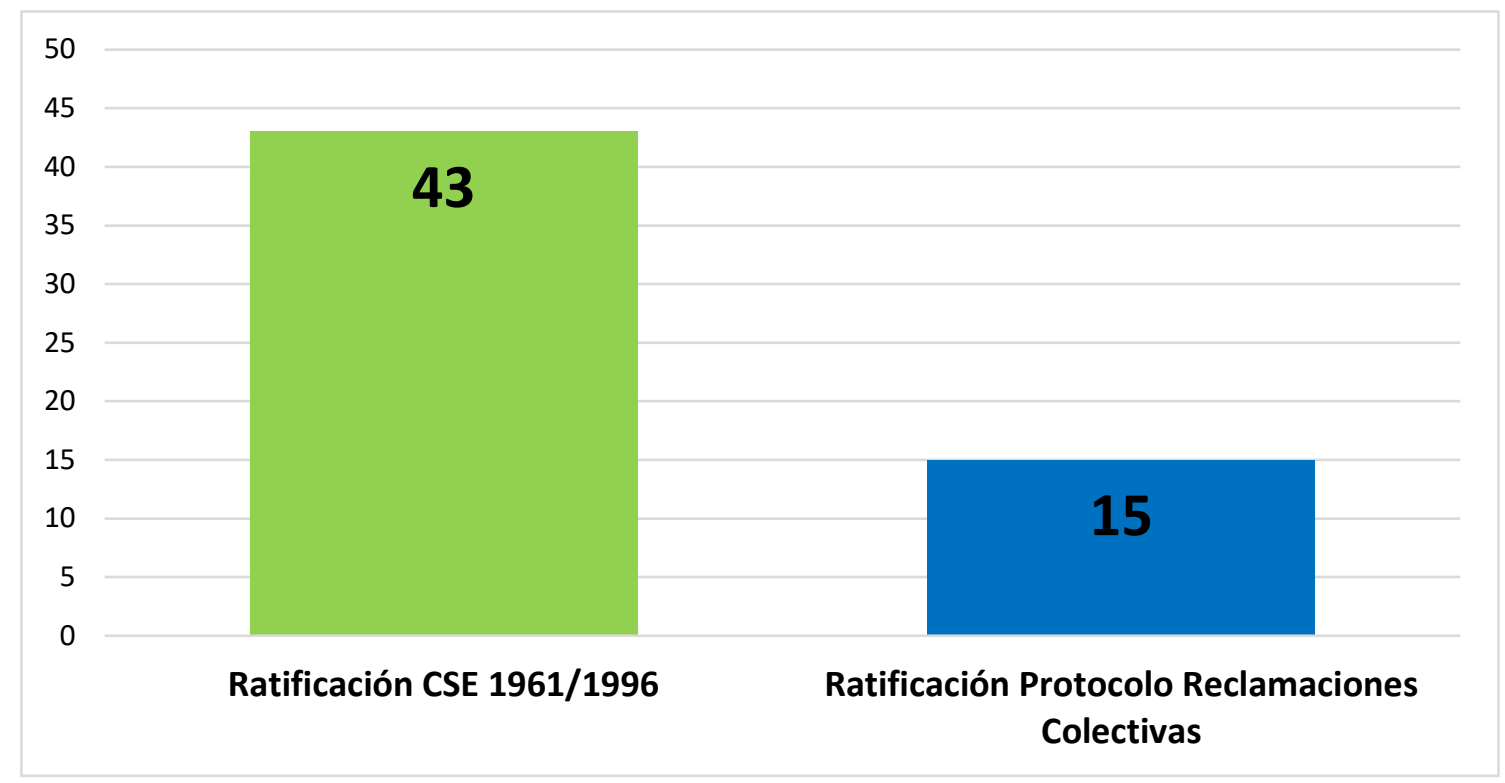

Tabla nº 11 Elaboración propia Fuente https://www.coe.int/fr/web/european-social-charter/signatures-ratifications, última actualización 21/3/19.

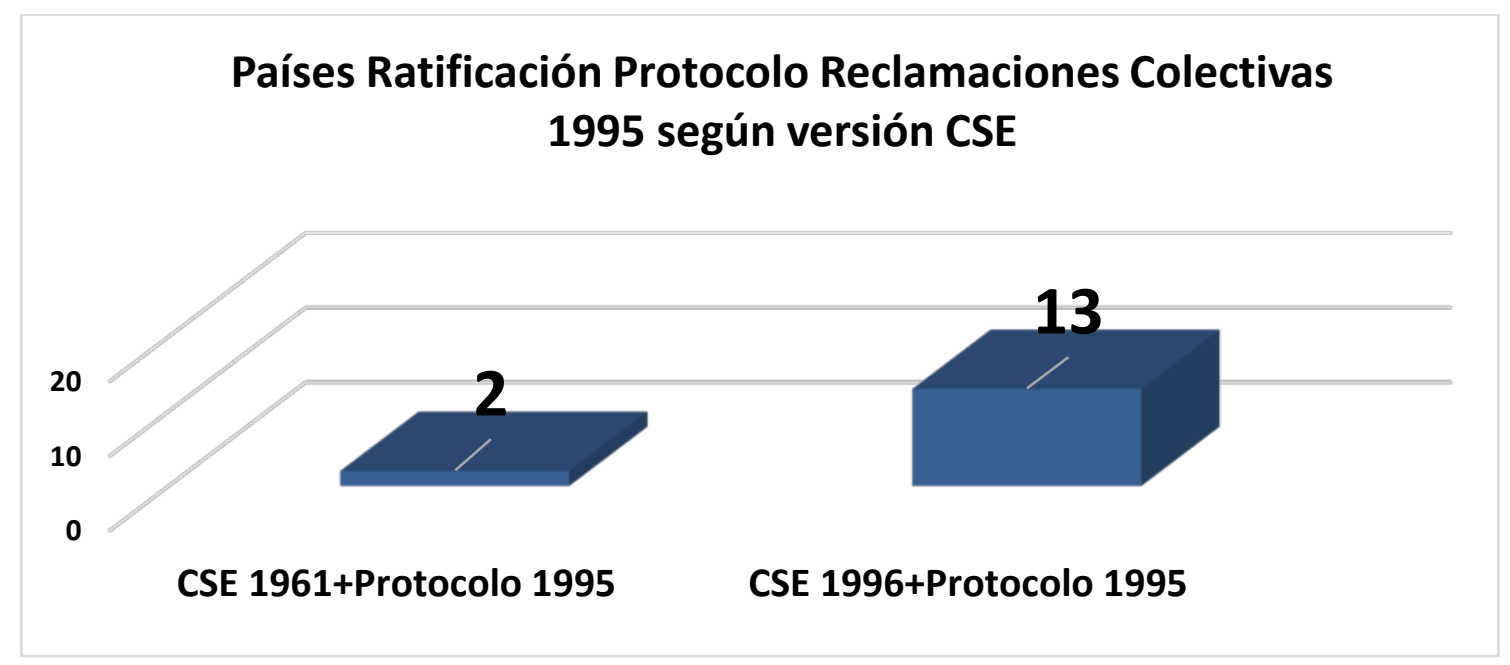

\footnotetext{
${ }^{54}$ Jimena Quesada, L. y Salcedo Beltrán, C., "La Carta Social Europea revisada (Constitución Social de Europa) y el Acuerdo del Consejo de Ministros: el compromiso con los derechos y ¿con sus garantías?”, en http://baylos.blogspot.com/2019/02/el-gobierno-debe-ratificar-la-carta.html, último acceso 24/3/19.

${ }^{55}$ Hasta el 18 de marzo de 2016, fecha en la que ratificó Grecia la versión revisada, también estaba en este listado)
} 
Tabla no 12 Elaboración propia Fuente https://www.coe.int/fr/web/european-social-charter/signatures-ratifications, última actualización 21/3/19

Si bien la norma que lo regula se denomina Protocolo, como el del PIDESC, presenta diferencias importantes, en particular las siguientes:

a) Tiene carácter “preventivo”, en el sentido de que se puede iniciar sin necesidad de demostrar que se han iniciado los efectos negativos de la norma o práctica que se impugna ya que se trata de que se dictamine su conformidad o no con la $\mathrm{CSE}^{56}$.

b) No es necesario agotar previamente los procedimientos jurisdiccionales nacionales.

c) No puede destinarse, como su denominación indica, para reclamaciones individuales, por lo que no se está ante un mecanismo que restablezca un derecho a una persona concreta ${ }^{57}$.

Están legitimadas las organizaciones internacionales de empleadores y de trabajadores ${ }^{58}$, las organizaciones nacionales representativas sometidas a la jurisdicción de la Parte Contratante contra la que se dirige la reclamación, las organizaciones internacionales no gubernamentales reconocidas como entidades consultivas por el Consejo de Europa y que figuren en la lista elaborada a tal fin por el Comité Gubernamental ${ }^{59}$ así como cualquier organización nacional no gubernamental no representativa que reconozca un Estado Contratante el derecho a presentar reclamaciones (arts. 1 y 2) ${ }^{60}$, no teniendo que ser estos sujetos víctimas directas de la vulneración, pues pueden actuar en representación de otros $^{61}$.

La reclamación se presenta por escrito, en la que se indica el precepto/s que no está siendo observado por el Estado, que será remitida al CEDS que se pronunciará, en un principio,

\footnotetext{
${ }^{56}$ BRILLAT, R., "La Procédure de Réclamations collectives de la Charte Sociale Européenne et la lutte contre la pauvreté», en AA.VV.: Pauvreté, Dignité, Droits de l'homme. Les 10 ans de l'accord de coopération. Service de lutte contre la pauvreté, la précarité et l'exclusion sociale. 2008, pp. 75 y 76. Extraído de http://www.luttepauvrete.be/rapport10ansaccord.htm (17/11/2017). Para un estudio completo véase AKANDJI-KOMBÉ, J.F., "L'application de la Charte Sociale Européenne: la mise en oeuvre de la procédure de réclamations collectives », Droit Social, 2000, n 9, pp. 888 a 896.

${ }^{57}$ Véase MARTINEZ OTERO, J.: "Controversias jurisdiccionales en materia social en Europa. Potenciales divergencias entre el Comité Europeo de Derechos Sociales y el Tribunal de Justicia de la Unión Europea”. Revista Europea de Derechos Fundamentales, 2009, nº 14. Pág. 287.

58 En concreto la Confederación Europea de Sindicatos (CES), la BusinessEurope (exUNICE) y la Organización Internacional de Empresarios (OIE).

59 El listado se puede encontrar en https://www.coe.int/fr/web/turin-european-social-charter/nongovernmental-organisations-entitled-to-lodge-collective-complaints (último acceso 21/4/18).

${ }^{60}$ Finlandia reconoció el 21 de agosto de 1998 a las ONG representativas de su país el derecho a interponer reclamaciones colectivas.

${ }^{61}$ Brillat, R., « La Procédure de Réclamations collectives de la Charte Sociale Européenne... », op. cit., p. 76.
} 
sobre su admisibilidad o no (decisión sur la recevabilité/decisión on admissibility). En el caso de producirse lo primero, instruye el procedimiento, en el que puede solicitar a las partes las aclaraciones, informaciones u observaciones escritas que procedan, así como organizar una audiencia con sus representantes (art. 7).

Una vez estudiada la controversia planteada, el CEDS adopta una decisión sobre el fondo (décision sur le bien-fondé/decision on the merits), de estructura muy similar a una sentencia, en la que se pronunciará sobre el asunto, que transmitirá a las partes y al Comité de Ministros, siendo publicada en un plazo máximo de cuatro meses.

El procedimiento finaliza con la emisión de una Resolución por el Comité de Ministros $y$, en su caso, de una Recomendación en la que determina que la normativa no es acorde con el articulado de la CSE e invita a la adopción de medidas al respecto, estando obligado el Estado a informar sobre su cumplimiento en el siguiente informe que presente.

España, como ya se apuntó, no lo ha ratificado. Ahora bien, se ha logrado que las reclamaciones y consiguientes decisiones de fondo de otros países, que interpretan preceptos que se tienen ratificados, desplieguen sus efectos en sede judicial española al presentarse las mismas situaciones. Así, en el año 2013 se emitió la primera sentencia del orden jurisdiccional social que resolvió una demanda favorable (SJS $n^{0} 2$ de Barcelona de 9 de noviembre de 2013) con fundamento en un precepto del Tratado (art. 4.4) y la jurisprudencia emitida en torno a la delimitación de su contenido por el CEDS en las decisiones de fondo de 23 de mayo de 2012 (Reclamaciones n ${ }^{\circ}$ 65/2011 y n ${ }^{\circ}$ 66/2011, Federación General de Trabajadores de la Empresa Nacional de Electricidad (GENOPDEI) y la Confederación de Funcionarios Públicos contra Grecia (ADEDY) contra Grecia.

Lejos de estar ante un pronunciamiento aislado, le siguieron otras sentencias a lo largo de los años 2014 y 2015, no sólo en asuntos que abordaron el mismo conflicto (entre otras, SJS n ${ }^{\circ} 1$ de Tarragona de 2 de abril de 2014, SJS de Mataró de 29 de abril de 2014, SJS $\mathrm{n}^{\circ} 3$ de Barcelona de 5 de noviembre de 2014, SJS n ${ }^{\circ} 9$ de Gran Canaria de 31 de marzo de 2015, SJS no 2 de Fuerteventura de 31 de marzo de 2015, SSJS nº 1 de Las Palmas de 11 de mayo, 3 de junio de 2015, SJS n 3 de Barcelona de 27 de octubre de 2015, SJS n ${ }^{\circ}$ 26 de Barcelona de 12 de marzo de 2018 y SJS n 3 de Talavera de la Reina de 29 de junio de 2018), sino también en otros, específicamente:

-La desvinculación de la revalorización pensiones atendiendo al índice de precios al consumo (SJS n ${ }^{\circ} 31$ de Barcelona de 8 de junio de 2015, n ${ }^{0} 12$ de 4 de septiembre de 2015 o n 3 de La Coruña de 23 de noviembre de 2015) -violación del art. 12.3 de la CSE y aplicación de las decisiones de fondo de 7 de diciembre de 2012, Reclamaciones ${ }^{0}$ 76, 77, 78, 79 y 80, presentadas por la Federación de pensionistas de Grecia (IKA-ETAM), la Federación Panhelénica de pensionistas de servicios públicos (POPS), el Sindicato de pensionistas del ferrocarril (ISAP), la Federación Panhelénica de pensionistas de la empresa pública de electricidad (POS-DEI), el Sindicato de pensionistas de la banca 
agrícola (ATE), la Federación General de Trabajadores de la Empresa Nacional de Electricidad (GENOP-DEI) y la Confederación de Funcionarios Públicos (ADEDY) contra Grecia -.

-La imposibilidad de asimilar a tiempo de descanso las guardias localizadas (SJS $\mathrm{n}^{\circ} 3$ de Barcelona de 27 de octubre de 2015) -incumplimiento del art. 2.1 de la CSE y aplicación de las decisiones de fondo de 8 de diciembre de 2004, Reclamaciones $\mathrm{n}^{\mathrm{0}} 16 \mathrm{y}$ 22/2003, Confédération Genérale du Travail, CGT Confédération française de l'Encadrement-Conféderation Générale de cadres, CFE-CGC y de 23 de junio de 2010, Reclamación n ${ }^{0}$ 55/2009, Confédération Genérale du Travail, CGT contra Francia-.

-Y el derecho a una renta mínima por encima del umbral de la pobreza (SJ contencioso-administrativo $\mathrm{n}^{\circ} 2$ de Valladolid de 21 de junio de 2018).

Aunque algunos de los pronunciamientos de primera instancia examinados han sido revocados por la siguiente, más remisa al reconocimiento del efecto "self-executing" de la CSE, durante el año 2016 y principios del 2017 algunos Tribunales Superiores de Justicia han continuado la interpretación, fallando de forma categórica en cuanto a la vinculación al Tratado y su efecto directo, así como a la consideración como “jurisprudencia” de los pronunciamientos del CEDS. Es el supuesto de los del TSJ de Canarias/Las Palmas de Gran Canaria de 28 de enero de 2016, Rec. 581/2015, 30 de marzo de 2016, Rec. 989/201, Castilla y León/Valladolid de 19 de diciembre de 2016, Rec. 2099/2016 o las más reciente, de nuevo el TSJ de Canarias/Las Palmas de Gran Canaria, de 31 de enero de 2017, Rec. 1300/2016, que literalmente resuelven de la CSE, que en derecho interno español, en virtud del art. 96 de la CE, es de "aplicación interna y directa”, pues "es derecho interno, y las disposiciones self-executing contenidas en la misma son inmediatamente aplicables a sus destinatarios y vinculan a los órganos judiciales y administrativos del Estado, del mismo modo que las demás normas jurídicas de producción interna”.

Sobre la más cuestionada vinculación a los pronunciamientos del CEDS y su valor, disponen que “(...) constituyen jurisprudencia que debe ser aplicada por los órganos jurisdiccionales nacionales”, siendo de plena aplicación “en la medida en que interpretan y delimitan el sentido de las reglas y preceptos que se contienen en la Carta, y que son en definitiva la interpretación auténtica del Tratado”, lo que obliga “a analizar a la luz de las normas y Tratados citados la legalidad [del asunto controvertido que se ha sometido]”.

No imposibilita el reconocimiento de la aplicabilidad de la norma internacional que el fallo, en algunas ocasiones, no haya sido favorable para el/la demandante, que se produce, en unos casos, porque se ha apreciado que el supuesto de hecho no era el mismo que del CEDS - no se alcanza la conclusión de que la falta de actualización de las pensiones determine que el nivel de protección social es insatisfactorio o de que se incumple la obligación del Estado de esforzarse por elevar el nivel del sistema de Seguridad Social (art. 12.3 de la CSE)-, y, en otros, porque que la solución ha de ser, no la nulidad del 
período de prueba, con la consiguiente improcedencia de la resolución contractual producida, sino la fijación de la indemnización correspondiente a la ausencia de preaviso razonable.

Esta permeabilidad a la CSE en la primera y segunda instancia judicial española, no está siendo, de momento, acompañada por las resoluciones del Tribunal Supremo que, con su “desfasada noción de jurisprudencia” 62 , inadmite los recursos de casación en unificación de doctrina de dos de las materias aludidas (Autos de 4 de noviembre de 2015, 30 de noviembre de 2016 o 20 de abril de 2017) en los que manifiesta la "falta de idoneidad" de las decisiones de fondo y las conclusiones del CEDS a los efectos de los requisitos exigidos por el art. 219 de la Ley 36/2011, de 10 de octubre, reguladora de la jurisdicción social. En todo caso, ni éstas ni las del Tribunal Constitucional, previas y posteriores a las señaladas con anterioridad, resolviendo la "constitucionalidad" de la normativa que ha originado las controversias ${ }^{63}$, impiden que prosiga la ejemplarizante doctrina judicial que opta por emplear el principio mencionado y el control de convencionalidad ${ }^{64}$, entendido como la obligación de los jueces de velar por que los efectos de las disposiciones de un tratado internacional “(...) no se vean mermadas por la aplicación de leyes contrarias a su objeto y fin” (Sentencia de la Corte Interamericana de Derechos Humanos de 26 de septiembre de 2006, asunto Almonacid Arellano y otros c. Chile.

Así lo acaba de interpretar recientemente el TC en la sentencia 140/2018, de 20 de diciembre de $2018^{65}$. En ella se aborda en el Fundamento Jurídico $6^{\circ}$ (FJ) si el contenido del análisis de constitucionalidad puede o debe incluir un examen sobre la compatibilidad entre tratados y la ley interna y, si ese eventual juicio, puede derivar en la declaración de inconstitucionalidad de una ley interna por oposición a un tratado, sobre la base de la

\footnotetext{
${ }^{62}$ Como señala de forma crítica JIMENA QUESADA, con esta interpretación el TS rememora "la obsoleta aproximación a la jurisprudencia del Código civil español (...), [se aleja] de los cánones jurisprudenciales europeos más recientes (...) [y con ello da cuerpo] a una anomalía en el sistema de fuentes del Derecho del Trabajo (...)”. En Devaluación y blindaje del Estado social y democrático...op. cit., p. 68.

${ }^{63}$ Entre otras, las SSTC 119/2014, de 16 de julio, 8/2015, de 22 de enero y 140/2015, de 22 de junio.

${ }^{64}$ Un estudio completo de la aplicación de las normas internacionales por estas instancias en GONZÁLEZ DE RIVERA I SERRA, X., "Conversaciones entre la norma internacional y la norma interna: la aplicación por los órganos judiciales", pp. 85 a 117 y JIMENA QUESADA, L., "La protección internacional de los derechos sociales y laborales: sinergias y voluntades del principio del favor libertatis", pp. 59 a 84, ambos en la obra colectiva coordinada por FARGAS FERNÁNDEZ, J., Los derechos laborales desde la perspectiva de la teoría general del contrato y de la normativa internacional, Barcelona, 2016, Huygens.

${ }^{65}$ Esta interpretación es mantenida desde hace años por JIMENA QUESADA que encabeza un sector doctrinal minoritario. Véase, entre otros trabajos suyos, "Control de constitucionalidad y control de convencionalidad: ¿un desafío para los Tribunales Constitucionales en la Unión Europea?”, en Ugartemendia, J.I., y Jáuregui, G. (coords.). Derecho Constitucional Europeo. Actas del VIII Congreso de la Asociación de Constitucionalistas de España, Valencia, Tirant lo Blanch, 2011, pp. 285-318, su libro Jurisdicción nacional y control de convencionalidad. A propósito del diálogo judicial global y de la tutela multinivel de derecho, Navarra, 2013, Aranzadi o el más reciente artículo "El control de convencionalidad y los derechos sociales: nuevos desafíos en España y en el ámbito comparado europeo (Francia, Italia y Portugal)”, Anuario Iberoamericano de Justicia Constitucional, 2018, no 22, pp. 31-58 y Salcedo Beltrán, C. "Derechos sociales y su garantía: la ineludible aprehensión, disposición e implementación de la Carta Social Europea (Constitución Social de Europa)". Revista de Derecho Social, 2018, n ${ }^{\circ}$ 83, pp. 45-74.
} 
previsión contenida en el artículo 96 de la Constitución Española. Las normas en particular objeto de examen son la Ley Orgánica 1/2014, de 13 de marzo, de modificación de la Ley Orgánica 6/1985, de 1 de julio, del Poder Judicial y el IV Convenio de Ginebra de protección de personas civiles en tiempo de guerra de 12 de agosto de 1949, pero, como se deducirá, la resolución es perfectamente extrapolable al resto de supuestos que puedan plantearse en cuanto al conflicto ley interna-tratado internacional (CSE, Convenios OIT...).

Reconociendo el órgano supremo que el precepto constitucional no contiene previsión expresa alguna relativa a la exigencia de que los jueces ordinarios formulen dicho control de convencionalidad ni existe tampoco esta previsión en relación con el Tribunal Constitucional, es indispensable determinar cuál es el órgano jurisdiccional competente para formularlo y su alcance. Para ello, precisa que el contenido del art. 96 de la CE “(...) no atribuye superioridad jerárquica a los tratados sobre las leyes internas” sino que "establece, de un lado, una regla de desplazamiento por parte del tratado de la norma interna anterior, sin que ello suponga su derogación, y, de otro, define la resistencia del tratado a ser derogado por las disposiciones internas posteriores en el tiempo", precisando que su realización no supone la exclusión de la norma interna del ordenamiento nacional, sino “su mera inaplicación”.

En suma, es concluyente al señalar que, en ningún momento, se enjuicia o se pretende una depuración del ordenamiento jurídico de normas inválidas sino “(...) su mera aplicabilidad”, que debe ser efectuada por los jueces y tribunales ordinarios, al tratarse de una cuestión de legalidad que excede del ámbito objetivo del Tribunal Constitucional remitiéndose a otras sentencias que con anterioridad ya se habían pronunciado en los mismos términos (SSTC 49/1988, de 22 de marzo, FJ 14; 28/1991, de 14 de febrero, FJ 5; 254/1993, de 20 de julio, FJ 5, y 12/2008, de 29 de enero, FJ 2).

Por tanto, la facultad propia de la jurisdicción para determinar la norma aplicable al supuesto controvertido se proyecta también a la interpretación de lo dispuesto en los tratados internacionales (STC 102/2002, FJ 7) así como al análisis de la compatibilidad entre una norma interna y una disposición internacional. Ello conlleva que, con fundamento en el art. 96 de la CE, “cualquier juez ordinario puede desplazar la aplicación de una norma interna con rango de ley para aplicar de modo preferente la disposición contenida en un tratado internacional, sin que de tal desplazamiento derive la expulsión de la norma interna del ordenamiento, como resulta obvio, sino su mera inaplicación al caso concreto" (entre otras, SSTC 102/2016, de 25 de mayo, 116/2016, de 20 de junio, y 127/2016, de 7 de julio).

Se trata de una actuación sencilla de "selección de derecho aplicable”, que, si bien queda extramuros de las competencias constitucionales, se encuadra perfectamente en las de la jurisdicción ordinaria, necesaria, legítima y exigida por el ordenamiento interno. 


\section{Reflexiones finales.}

A lo largo de este estudio se ha podido comprobar cómo los ciudadanos están exigiendo a las responsables gubernamentales los derechos que tienen reconocido a nivel internacional.

En el supuesto de que esa demanda no es atendida, los órganos judiciales se convierten en la instancia a la que recurren con el objeto de que restablezcan el derecho reconocido y garantizado, en aplicación del control de convencionalidad.

Así lo legitiman y fundamentan las sentencias aludidas en el apartado anterior, con base en el art. 96.1 de la CE, desarrollado por los arts. 29 (“Todos los poderes públicos, órganos y organismos del Estado deberán respetar las obligaciones de los tratados internacionales en vigor en los que España sea parte y velar por el adecuado cumplimiento de dichos tratados”), 30 (“Los tratados internacionales serán de aplicación directa (...)”) y 31 (“Las normas jurídicas contenidas en los tratados internacionales válidamente celebrados y publicados oficialmente prevalecerán sobre cualquier otra norma del ordenamiento interno en caso de conflicto con ellas, salvo las normas de rango constitucional”) de la Ley 25/2014, de 27 de noviembre, de Tratados y otros Acuerdos Internacionales, que determinan la plena aplicabilidad de la norma jerárquicamente superior, más favorable (favor libertatis) así como de la interpretación auténtica que ha efectuado el órgano supervisor del mismo.

El ordenamiento jurídico está integrado por un conjunto de fuentes, nacionales e internacionales, que deben ser observadas en términos equivalentes, el progreso de un país se valora atendiendo a ese parámetro, es decir, el respeto de los derechos reconocidos y sus garantías.

La paz, la democracia y el Estado Social deben ser recuperados y salir reforzados de la crisis y para ello los Tratados internacionales de derechos humanos, en particular la CSE y el PIDESC, son los instrumentos fundamentales para su (re)conquista e, inherentes a ellos, las interpretaciones vinculantes de sus órganos de supervisión que, en suma, se dirigen a garantizar y hacer efectivas las condiciones básicas e inherentes a la dignidad humana. 